\title{
Multi-variable evaluation of hydrological model predictions for a headwater basin in the Canadian Rocky Mountains
}

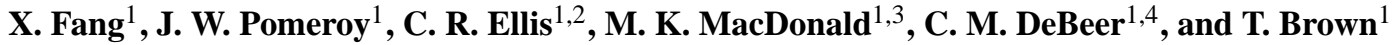 \\ ${ }^{1}$ Centre for Hydrology, University of Saskatchewan, Saskatoon, Canada \\ ${ }^{2}$ Silvatech Consulting Ltd., Salmon Arm, Canada \\ ${ }^{3}$ School of Geosciences, University of Edinburgh, Edinburgh, UK \\ ${ }^{4}$ Global Institute for Water Security, Saskatoon, Canada
}

Correspondence to: X. Fang (xif382@mail.usask.ca)

Received: 31 October 2012 - Published in Hydrol. Earth Syst. Sci. Discuss.: 13 November 2012

Revised: 23 March 2013 - Accepted: 25 March 2013 - Published: 30 April 2013

\begin{abstract}
One of the purposes of the Cold Regions Hydrological Modelling platform (CRHM) is to diagnose inadequacies in the understanding of the hydrological cycle and its simulation. A physically based hydrological model including a full suite of snow and cold regions hydrology processes as well as warm season, hillslope and groundwater hydrology was developed in CRHM for application in the Marmot Creek Research Basin $\left(\sim 9.4 \mathrm{~km}^{2}\right)$, located in the Front Ranges of the Canadian Rocky Mountains. Parameters were selected from digital elevation model, forest, soil, and geological maps, and from the results of many cold regions hydrology studies in the region and elsewhere. Non-calibrated simulations were conducted for six hydrological years during the period 2005-2011 and were compared with detailed field observations of several hydrological cycle components. The results showed good model performance for snow accumulation and snowmelt compared to the field observations for four seasons during the period 2007-2011, with a small bias and normalised root mean square difference (NRMSD) ranging from 40 to $42 \%$ for the subalpine conifer forests and from 31 to $67 \%$ for the alpine tundra and treeline larch forest environments. Overestimation or underestimation of the peak SWE ranged from 1.6 to $29 \%$. Simulations matched well with the observed unfrozen moisture fluctuation in the top soil layer at a lodgepole pine site during the period 2006-2011, with a NRMSD ranging from 17 to $39 \%$, but with consistent overestimation of 7 to $34 \%$. Evaluations of seasonal streamflow during the period 2006-2011 revealed that the model generally predicted well compared to observations at the basin scale, with a NRMSD of $60 \%$ and small model bias (1\%),
\end{abstract}

while at the sub-basin scale NRMSDs were larger, ranging from 72 to $76 \%$, though overestimation or underestimation for the cumulative seasonal discharge was within $29 \%$. Timing of discharge was better predicted at the Marmot Creek basin outlet, having a Nash-Sutcliffe efficiency (NSE) of 0.58 compared to the outlets of the sub-basins where NSE ranged from 0.2 to 0.28 . The Pearson product-moment correlation coefficient of 0.15 and 0.17 for comparisons between the simulated groundwater storage and observed groundwater level fluctuation at two wells indicate weak but positive correlations. The model results are encouraging for uncalibrated prediction and indicate research priorities to improve simulations of snow accumulation at treeline, groundwater dynamics, and small-scale runoff generation processes in this environment. The study shows that improved hydrological cycle model prediction can be derived from improved hydrological understanding and therefore is a model that can be applied for prediction in ungauged basins.

\section{Introduction}

The Canadian Rockies are an important water source for northern North America; they form the headwaters of the eastward flowing Saskatchewan and Athabasca Rivers, whose water supplies are crucial to the urban centres of Alberta and Saskatchewan such as Edmonton, Calgary, Saskatoon, and Regina as well as to the agricultural sector and oil sands mining operations. The western slopes are the headwaters of the Columbia and Fraser Rivers, whose water supports 
hydroelectricity generation, agriculture and municipalities in southern British Columbia and the US Pacific Northwest. Water supplies from runoff in the eastward flowing Canadian Rockies drainages have been declining (St. Jacques et al., 2010) and are predicted to drop further just as increasing demand is projected due to rising population and greater consumption from downstream agriculture and industry (Mannix et al., 2010). The Canadian Rockies are typical of many cold regions mountain ranges in that they have substantial snow accumulation in the winter and melt in spring and summer and so provide water for drier regions downstream during times of important agricultural and human consumption demand. By better understanding the hydrology of the Canadian Rockies, it is possible to better understand mountain hydrology in general with global applications.

Mountain runoff in this region is sensitive to climate variations. It is suggested that the rising number of winter days with air temperature above the freezing point (Lapp et al., 2005) and decreases in spring snowcover extent (Brown and Robinson, 2011) are resulting in earlier spring runoff (Stewart et al., 2004) and lower annual streamflows (St. Jacques et al., 2010). These climate changes have been associated with increasing rates of forest disturbance due to wildfire (Fauria and Johnson, 2006), insect infestation (Aukema et al., 2008), and disease (Woods et al., 2005). The hydrological cycle in mountain environments can be substantially altered by forest disturbance, leading to increased snow accumulation and snowmelt rates (Pomeroy and Gray, 1995; Boon, 2009; Burles and Boon, 2011; Pomeroy et al., 2012), enhanced surface runoff and peak flow (Whitaker et al., 2002; Pomeroy et al., 2012), and changing groundwater regimes (Rex and Dubé, 2006).

Many cold regions mountain basins are dominated by needleleaf forest cover, where snowmelt is the most important annual hydrological event (Gray and Male, 1981). Needleleaf forest foliage substantially reduces snow accumulation, with declines ranging from 30 to $50 \%$ compared to adjacent clearing sites (Pomeroy et al., 2002; Gelfan et al., 2004). The losses of snow accumulation in forests are attributed to the interception of snow by the evergreen needleleaf canopy (Lundberg and Halldin, 1994; Pomeroy and Gray, 1995; Hedstrom and Pomeroy, 1998; Gelfan et al., 2004). This intercepted snow is exposed to high rates of turbulent transfer and radiation input and so sublimates rapidly (Pomeroy et al., 1998), resulting in greatly reduced snow accumulation on the ground at the time of snowmelt (Pomeroy and Gray, 1995). However, snow unloading response to energy inputs adds uncertainty about the partition of snowfall between interception and unloading by the forest canopies, and further development of these algorithms for mountain slopes and forests is needed (Rutter et al., 2009). Apart from interception effects, needleleaf forest cover also affects energy exchanges to snow and therefore the timing and duration of snowmelt. The forest canopy dampens turbulent energy fluxes when compared with open snowfields (Harding and Pomeroy, 1996; Reba et al., 2012). As a result, energy to melt sub-canopy snow is dominated by radiation fluxes, which in turn are altered by extinction of shortwave transmission through the canopy and enhancement of longwave emission from canopies and trunks (Link et al., 2004; Sicart et al., 2004; Essery et al., 2008; Boon, 2009; Pomeroy et al., 2009; Ellis et al., 2013; Varhola et al., 2010).

Elevation exerts a strong influence on air temperature, precipitation depth, and phase in mountain basins (Storr, 1967; Marks et al., 2013), while slope and aspect are the additional factors controlling the patterns of snow accumulation and snowmelt in the mountain environments (Golding and Swanson, 1986; Pomeroy et al., 2003; DeBeer and Pomeroy, 2009; MacDonald et al., 2010; Ellis et al., 2011; Marsh et al., 2012). At high elevations above treeline, snow is redistributed by wind (Föhn and Meister, 1983; Doorschot et al., 2001; Bernhardt et al., 2009), of which some is lost via sublimation to the atmosphere (MacDonald et al., 2010).

Temperate zone models have great difficulty in simulating the hydrological cycle of cold mountain regions (Swanson, 1998), and there remains a need for a model that is suitable for river basins originating in the Canadian Rockies. Cold regions hydrological processes have been represented in hydrological models such as ARHYTHM (Zhang et al., 2000), VIC (Bowling et al., 2004), and GENESYS (MacDonald et al., 2011). However, the Cold Regions Hydrological Modelling platform (CRHM) offers a more complete range of processes for the Canadian Rockies (i.e. blowing snow, interception and sublimation of snow, energy balance snowmelt, slope radiation, canopy influence on radiation, canopy gap effect on snow, infiltration to frozen soils) and the process algorithms have been extensively field tested. CRHM is a modular model assembling system that allows appropriate hydrological processes to be linked for simulating basin hydrological cycle (Pomeroy et al., 2007). The underlying philosophy is to use CRHM to create a model of appropriate physical and spatial complexity for the level of understanding and information available for the basin being modelled. Insight from field investigations has largely guided CRHM's development, with the expectation that an improved understanding of the underlying hydrological processes will yield benefits in terms of prediction capability, and so new algorithms from field studies have been incorporated as modules in the platform. For example, new algorithms recently added to CRHM include those for estimating shortwave radiation through forest canopies on slopes (Ellis and Pomeroy, 2007), calculating enhanced longwave emissions from canopies (Pomeroy et al., 2009), and estimating snow surface temperature (Ellis et al., 2010). CRHM also now accounts for canopy gap radiative transfer and unloading of intercepted snow in a mass and energy module for needleleaf forests (Ellis et al., 2010, 2013). Other recent additions are modules for simulating blowing snow and sublimation affected by local wind and topography in the alpine treeline environment (MacDonald et al., 2010), improved simulation for the alpine snowmelt and 
snowmelt runoff (DeBeer and Pomeroy, 2010), and improved soil system representation for runoff generation (Dornes et al., 2008a; Fang et al., 2010).

A physically based hydrological model incorporating these recent developments was set up using CRHM to simulate forest snow hydrology in a headwater basin of the Canadian Rockies; preliminary tests showed adequate predictions for snow accumulation, melt, and snowmelt runoff (Pomeroy et al., 2012). More recent model developments have focused on incorporating a more physically realistic soil and groundwater system in the model and simulating groundwater-surface-water interactions on hillslopes to improve simulation of soil moisture, evapotranspiration, baseflow, and groundwater storage. A comprehensive model addressing all major processes in the basin hydrological cycle that can be parameterised based on field and remote sensing measurements is expected to be a powerful and robust tool for examining the impacts of land use and climate change on basin runoff response. Such a tool would also provide a basis for identifying regionalised parameterisations for modelling similar but ungauged basins in the region or similar cold mountain environments (Dornes et al., 2008b) as well as helping identify those physical processes most critical in controlling the large-scale hydrology of the region (Pietroniro et al., 2007). Another advantage of models like CRHM is that they may be evaluated using multiple objectives to avoid equifinality problems (Bevan and Freer, 2001) by allowing a much more powerful evaluation of the model as a representation of many aspects of the hydrological cycle (Dornes et al., 2008b). Considering these issues, the objectives of this paper are the following: (1) to propose a comprehensive physically based model to simulate all the relevant hydrological processes for a headwater basin of the Canadian Rocky Mountains; (2) to evaluate the model performance against the field observations, including winter snow accumulation, spring snowmelt, spring and summer soil moisture fluctuation, streamflow discharge, and groundwater level fluctuation without any parameter calibration from streamflow records. Estimation of unmeasured model parameters is not by calibration to observed streamflow but by regionalisation based on detailed process research in environmentally similar regions or in the basin itself, as proposed by Kuchment et al. (2000) and demonstrated in cold regions mountains by Semenova et al. (2013), where model structure is chosen based on analyses of runoff generation processes at a research basin. It is expected that this will not only assess our understanding of hydrology in this environment, but substantially advance the practice of hydrological prediction for ungauged basins, and provide a predictive tool that is sufficiently robust for describing hydrological responses in nonstationary environments.

\section{Study area and field observations}

\subsection{Site description}

The study was conducted in the Marmot Creek Research Basin (MCRB) $\left(50^{\circ} 57^{\prime} \mathrm{N}, 115^{\circ} 09^{\prime} \mathrm{W}\right)$, Kananaskis Valley, Alberta, Canada, located within the Front Ranges of the Canadian Rocky Mountains (Fig. 1a). Marmot Creek is a tributary of the Kananaskis River and is a headwater basin of the Bow River basin. The MCRB totals $9.4 \mathrm{~km}^{2}$ and is composed of three upper sub-basins: Cabin Creek $\left(2.35 \mathrm{~km}^{2}\right)$, Middle Creek $\left(2.94 \mathrm{~km}^{2}\right)$, and Twin Creek $\left(2.79 \mathrm{~km}^{2}\right)$, which converge into the confluence sub-basin above the main stream gauge $\left(1.32 \mathrm{~km}^{2}\right)$. Elevation ranges from $1600 \mathrm{~m}$ a.s.l. (above sea level) at the main streamgauge to $2825 \mathrm{~m}$ at the summit of Mount Allan. Most of MCRB is covered by needleleaf vegetation which is dominated by Engelmann spruce (Picea engelmanni) and subalpine fir (Abies lasiocarpa) in the higher elevations and lodgepole pine ( $P i$ nus contorta var. Latifolia) in the lower elevations (Kirby and Ogilvy, 1969). Forest management experiments conducted in the 1970s and 1980s left large clear-cutting blocks in the Cabin Creek sub-basin and numerous small circular clearings in the Twin Creek sub-basin (Golding and Swanson, 1986). Alpine larch (Larix lyallii) and short shrub are present around the treeline at approximately 2180 to $2250 \mathrm{~m}$, and exposed rock surface and taluses are present in the high alpine part of basin. The basin experiences seasonally frozen soils, and surficial materials are primarily poorly developed mountain soils consisting of glaciofluvial and till surficial deposits (Beke, 1969). Relatively impermeable bedrock is found at the higher elevations and headwater areas, while the rest of basin is covered by a deep layer of coarse and permeable soil allowing for rapid rainfall infiltration to subsurface layers overlying relatively impermeable shale (Jeffrey, 1965). In general, continental air masses control the weather in the region, which has long and cold winters and cool and wet springs. Westerly warm and dry Chinook (foehn) winds lead to brief periods with the air temperature above $0^{\circ} \mathrm{C}$ during the winter months. In the MCRB, annual precipitation ranges from $600 \mathrm{~mm}$ at lower elevations to more than $1100 \mathrm{~mm}$ at the higher elevations, of which approximately 70 to $75 \%$ occurs as snowfall, with the percentage increasing with elevation (Storr, 1967). Mean monthly air temperature ranges from $14^{\circ} \mathrm{C}$ in July to $-10^{\circ} \mathrm{C}$ in January.

\subsection{Field observations}

Model forcing meteorological observations of air temperature, relative humidity, wind speed, precipitation, soil temperature, and incoming shortwave radiation were collected from the Centennial Ridge, Fisera Ridge, Vista View, Upper Clearing and Upper Forest, Level Forest, and Hay Meadow hydrometeorological stations. The locations of these meteorological stations in the MCRB are shown in Fig. 1a, which 

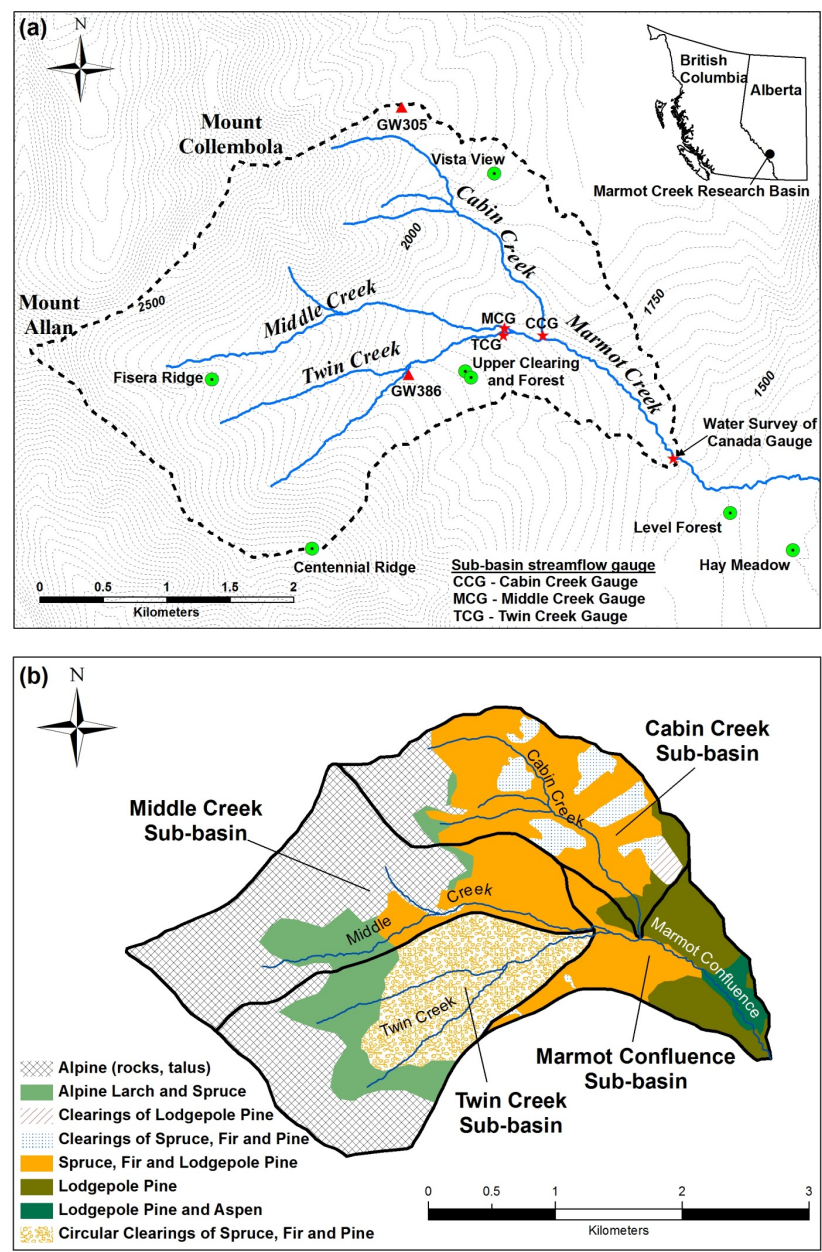

Fig. 1. (a) Contour map (m) of the Marmot Creek Research Basin (MCRB) showing stream names, the locations of groundwater wells (GW, red triangular), hydrometeorological stations (green dot circles) and streamflow gauge stations (red star), and (b) landcover types corresponding to the major forest zones. Note that the area where there are small irregular circular clearings is shown, but size of clearings is too small to be shown at this scale.

are described in several recent publications (DeBeer and Pomeroy, 2010; Ellis et al., 2010; MacDonald et al., 2010). Precipitation was measured with an Alter-shielded Geonor weighing precipitation gauge at Hay Meadow, Upper Clearing, and Fisera Ridge and was corrected for wind-induced undercatch (MacDonald and Pomeroy, 2007). Meteorological data were spatially distributed across the basin with adjustments for temperature by a constant environmental lapse rate $\left(0.75^{\circ} \mathrm{C} / 100 \mathrm{~m}\right)$ and adjustments for precipitation based on observed seasonal gradients from several years of observations at multiple elevations. Vapour pressure was conserved for unsaturated conditions and not allowed to exceed saturation vapour pressure when extrapolated. Radiation inputs were adjusted for slope and sky view using the various methods outlined in the next section.
Snow surveys were conducted over the winter and spring from transects established near the meteorological stations. For each snow survey transect, at least 25 snow depth measurements with a ruler and at least 6 gravimetric snow density measurements with an ESC-30 snow tube were collected to estimate snow water equivalent (SWE). Soil moisture (0$25 \mathrm{~cm}$ ) was continuously measured with Campbell Scientific CS616 soil moisture probes at Upper Clearing, Upper Forest and Level Forest stations (Fig. 1a). Environment Canada's Water Survey of Canada maintains a long-term streamflow gauge (05BF016) at the Marmot Creek basin outlet shown in Fig. 1a, providing seasonal (1 May-31 October) daily mean streamflow discharge. Additional measurements of streamflow were conducted at the outlets of Cabin Creek, Middle Creek and Twin Creek sub-basins (Fig. 1a) starting from spring 2007. Flow depth was measured with automated pressure transducers and discharge was calculated from velocity and depth profiles taken every few weeks from spring to autumn for these sub-basin outlets. Several groundwater wells were established at the MCRB in 1960s and were continuously monitored until the mid-1980s. Some of these wells were re-activated in the mid-1990s; from these, recent data (December 2005-July 2010) were obtained from Alberta Environment and Sustainable Resource Development for the two wells GW305 and GW386 shown in Fig. 1a.

\section{Model setup and parameterisation}

\subsection{Cold Regions Hydrological Modelling platform}

The Cold Regions Hydrological Modelling platform (CRHM) was used to develop a basin hydrological model to simulate the dominant hydrological processes in alpine and forested environments at the MCRB. CRHM is an object-oriented, modular and flexible platform for assembling physically based hydrological models. With CRHM, the user constructs a purpose-built model or "project" from a selection of possible basin spatial configurations, spatial resolutions, and physical process modules of varying degrees of physical complexity. Basin discretisation is performed via dynamic networks of hydrological response units (HRUs) whose number and nature are selected based on the variability of basin attributes and the level of physical complexity chosen for the project. Physical complexity is selected by the user in light of hydrological understanding, parameter availability, basin complexity, meteorological data availability, and the objective flux or state for prediction. Models are chosen depending on the dominant hydrological processes and controls on the basin. A full description of CRHM is provided by Pomeroy et al. (2007).

A set of physically based modules was constructed in a sequential manner to simulate the dominant hydrological processes for the MCRB. Figure 2 shows the schematic setup of these modules, which include the following: 


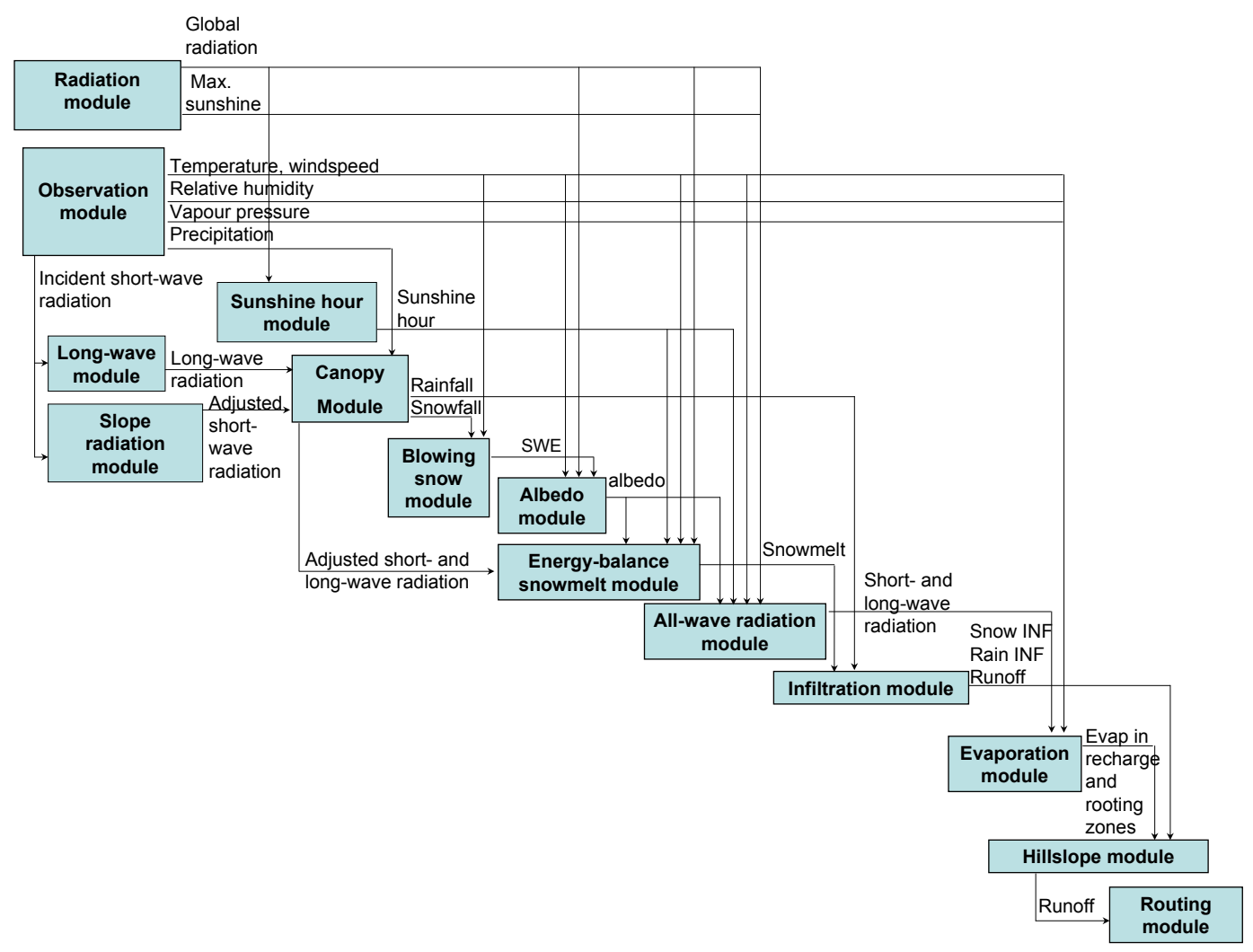

Fig. 2. Flowchart depicting the configuration of physically based hydrological modules in CRHM for simulating hydrological processes. This setup is repeated for each HRU to develop a mountain hydrology model in the Marmot Creek Research Basin.

1. Observation module: reads the forcing meteorological data (temperature, wind speed, relative humidity, vapour pressure, precipitation, and radiation), adjusting temperature with environmental lapse rate and precipitation with elevation and wind-induced undercatch, and providing these inputs to other modules.

2. Radiation module (Garnier and Ohmura, 1970): calculates the theoretical global radiation, direct and diffuse solar radiation, as well as maximum sunshine hours based on latitude, elevation, ground slope, and azimuth, providing radiation inputs to the sunshine hour module, the energy-budget snowmelt module, and the net all-wave radiation module.

3. Sunshine hour module: estimates sunshine hours from incoming shortwave radiation and maximum sunshine hours, generating inputs to the energy-balance snowmelt module and the net all-wave radiation module.

4. Slope radiation module: estimates incident shortwave to a slope using measurement of incoming shortwave radiation on a level surface. The measured incoming shortwave radiation from the observation module and the calculated direct and diffuse solar radiation from the radiation module are used to calculate the ratio for adjusting the shortwave radiation on the slope.

5. Longwave radiation module (Sicart et al., 2006): estimates incoming longwave radiation using measured shortwave radiation. This is inputted to the energybalance snowmelt module.

6. Albedo module (Verseghy, 1991): estimates snow albedo throughout the winter and into the melt period and also indicates the beginning of melt for the energybalance snowmelt module.

7. Canopy module (Ellis et al., 2010): estimates the snowfall and rainfall intercepted by the forest canopy and updates the under-canopy snowfall and rainfall and calculates shortwave and longwave sub-canopy radiation. This module has options for open environment (no canopy adjustment of snow mass and energy), small forest clearing environment (adjustment of snow mass and energy based on diameter of clearing and surrounding forest height), and forest environment (adjustment of snow mass and energy from forest canopy).

8. Blowing snow module (Pomeroy and Li, 2000): simulates the inter-HRU wind redistribution of snow 


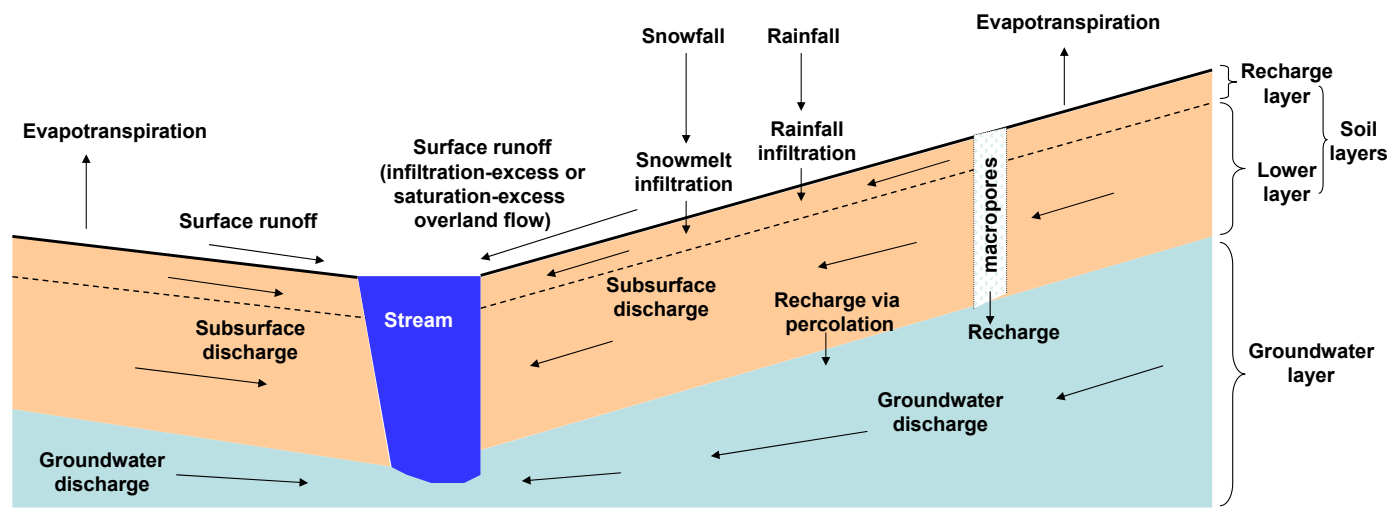

Fig. 3. Conceptual representation of CRHM's hillslope module with control volumes of two soil layers, groundwater layer, and surface depressions or macropores and their interactions. Note that saturated porous media flow always occurs in the groundwater layer and can episodically occur in the soil layers.

transport and blowing snow sublimation losses throughout the winter period.

9. Energy-balance snowmelt module (Marks et al., 1998): this is a version of the SNOBAL model developed to simulate the mass and energy balance of deep mountain snowpacks. This module estimates snowmelt and flow through snow by calculating the energy balance of radiation, sensible heat, latent heat, ground heat, advection from rainfall, and the change in internal energy for snowpack layers consisting of a top active layer and a layer underneath it.

10. All-wave radiation module (Granger and Gray, 1990): calculates the net all-wave radiation from shortwave radiation for input to the evaporation module for snowfree conditions.

11. Infiltration module: Gray's parametric snowmelt infiltration algorithm (Zhao and Gray, 1999) estimates snowmelt infiltration into frozen soils; Ayers' infiltration (Ayers, 1959) estimates rainfall infiltration into unfrozen soils based on soil texture and ground cover. Both infiltration algorithms link moisture content to the soil column in the hillslope module. Surface runoff forms when snowmelt or rainfall exceeds the infiltration rate.

12. Evaporation module: Granger's evaporation expression (Granger and Gray, 1989; Granger and Pomeroy, 1997) estimates actual evapotranspiration from unsaturated surfaces using an energy balance and extension of Penman's equation to unsaturated conditions; Priestley and Taylor evaporation expression (Priestley and Taylor, 1972) estimates evaporation from saturated surfaces such as stream channels. Both evaporation algorithms modify moisture content in the interception store, ponded surface water store, and soil column, and are restricted by water availability to ensure continuity of mass, and the Priestley and Taylor evaporation also updates moisture content in the stream channel.

13. Hillslope module: this recently developed module is for calculating subsurface flow and simulating groundwater-surface-water interactions using physically based parameters and principles on hillslopes. This module was revised from an original soil moisture balance routine developed by Leavesley et al. (1983) and modified by Dornes et al. (2008a) and Fang et al. (2010) - it now calculates the soil moisture balance, groundwater storage, subsurface and groundwater discharge, depressional storage, and runoff for control volumes of two soil layers, a groundwater layer, and surface depressions. A conceptual representation of this module is shown in Fig. 3. In this diagram, the top layer is called the recharge layer, which obtains inputs from infiltration of ponded surface water, snowmelt or sub-canopy rainfall. Evaporation first extracts water from canopy interception and surface storage and then can withdraw moisture via transpiration from only the recharge layer or from both soil column layers, depending on rooting characteristics, and is restricted to plant available soil moisture (Armstrong et al., 2010). Evaporation does not withdraw soil moisture until canopy interception and surface water storage are depleted. Groundwater recharge occurs via percolation from the soil layers or directly from depressional storage via macropores. Subsurface discharge occurs via horizontal drainage from either soil layer; groundwater discharge takes place through horizontal drainage in the groundwater layer. Surface runoff occurs if snowmelt or rainfall inputs exceed subsurface withdrawals from saturated soils or if the rate of snowmelt or rainfall exceeds the infiltration rate.

14. Routing module: the Muskingum method is based on a variable discharge-storage relationship (Chow, 1964) 


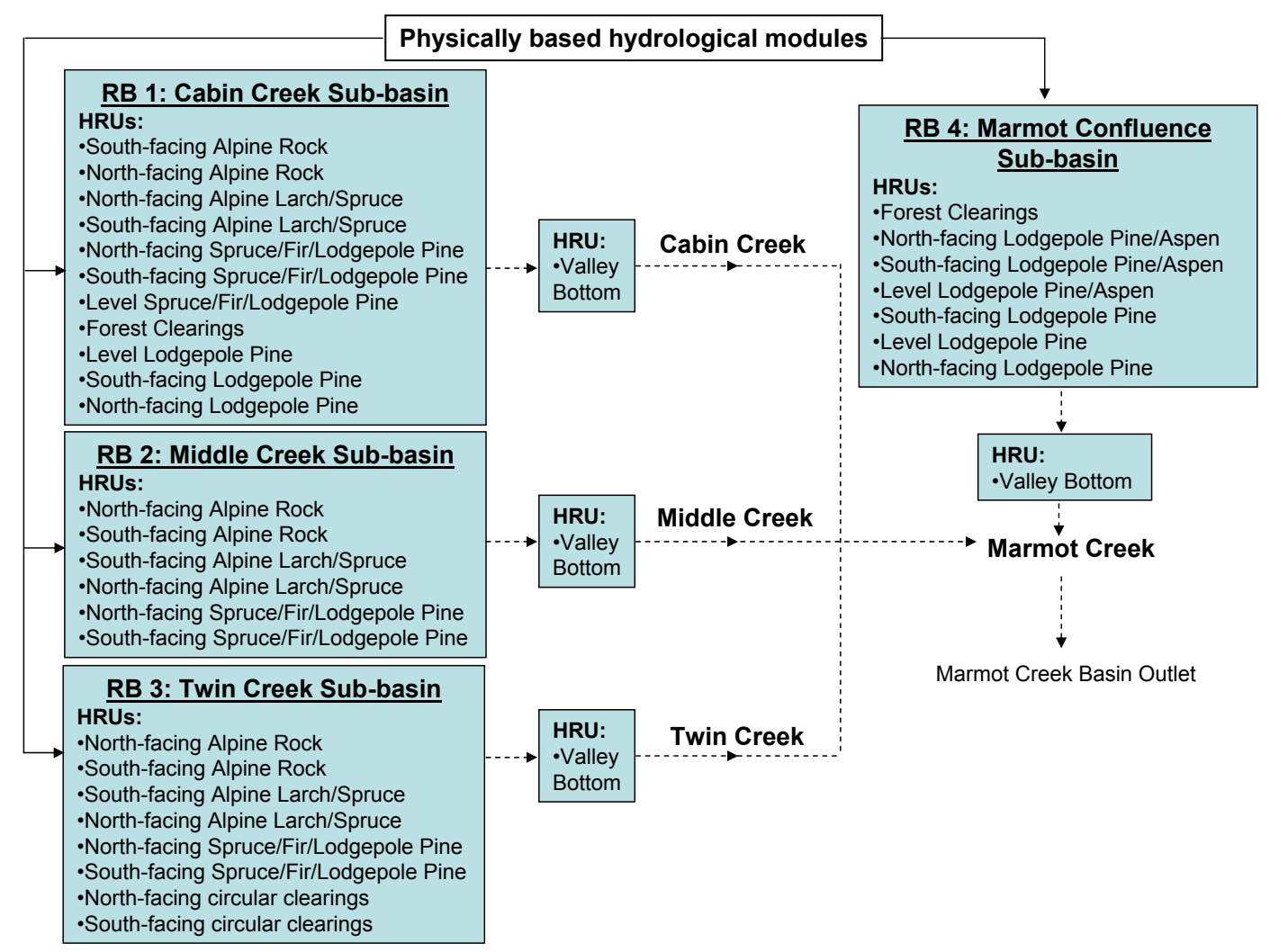

Fig. 4. CRHM modelling structure. The four sub-basins comprising Marmot Creek are simulated as "representative basins" (RBs) which are composed of various HRUs (listed in blue boxes), and each HRU contains the physically based hydrological module internal structure shown in Fig. 2. Muskingum routing (shown by the dashed line) routes flow from non-channel HRUs to valley bottom HRU in each RB and then connects all four RBs and routes flow to the basin outlet.

and is used to route runoff between HRUs in the subbasins. The routing storage constant is estimated from the average distance from the HRU to the main channel and average flow velocity; the average flow velocity is calculated by Manning's equation (Chow, 1959) based on the average HRU distance to the main channel, average change in HRU elevation, overland flow depth and HRU roughness. For the subsurface and ground water flows, Clark's lag and route algorithm (Clark, 1945) is used.

\subsection{Model parameter estimation}

\subsubsection{Basin physiographic parameters}

A CRHM modelling structure termed the "representative basin" (RB) was used to simulate the hydrological processes for sub-basins in the MCRB. In a RB, a set of physically based modules are assembled with a number of HRUs; the $\mathrm{RB}$ can be repeated as necessary for a basin, with each subbasin possessing the same module configuration but varying parameter sets and varying numbers of HRUs. For the model application, the MCRB was divided into four subbasins that are represented by four separate RBs (Fig. 4) for which a modelling structure comprising of Muskingum routing was used to route the streamflow output from these RBs along the main channels in the MCRB: Cabin Creek, Middle Creek, Twin Creek, and Marmot Creek. HRUs were decided based on combination of forest cover, aspect, and slope characteristics. The forest cover types were derived from the existing basin forest cover maps by the Alberta Forest Service (1963) with recent changes updated from site visits. Figure $1 \mathrm{~b}$ shows the updated cover types including alpine taluses and exposed rock, alpine forest, mixed forest of spruce and lodgepole pine, mixed forest of lodgepole pine and aspen, lodgepole pine forest, and forest clearings. A terrain preprocessing GIS analysis using a 2008 lidar 8-m digital elevation model (DEM) (Hopkinson et al., 2012) was employed to extract elevation, aspect, and slope for the basin. The extracted elevation, aspect, and slope were then intersected with the basin forest cover feature in ArcGIS, which generates the HRUs based on elevation, aspect, slope, and forest cover (Fig. 5). For the Cabin Creek sub-basin, 12 HRUs were generated, and 7,9, and 8 HRUs were extracted for Middle Creek, Twin Creek, and Marmot Creek confluence sub-basins, respectively. The area and the averaged values of elevation, aspect, and slope for these HRUs are listed in Table 1. 
Table 1. Area and mean elevation, aspect, and slope for HRUs in sub-basins of the Marmot Creek Research Basin. Note that the aspect is in degree clockwise from north.

\begin{tabular}{lccrr}
\hline HRU name & $\begin{array}{c}\text { Area } \\
\left(\mathrm{km}^{2}\right)\end{array}$ & $\begin{array}{r}\text { Mean } \\
\text { elevation } \\
(\mathrm{m} \text { a.s.l })\end{array}$ & $\begin{array}{r}\text { Mean } \\
\text { aspect } \\
\left({ }^{\circ}\right)\end{array}$ & $\begin{array}{r}\text { Mean } \\
\text { slope } \\
\left({ }^{\circ}\right)\end{array}$ \\
\hline \multicolumn{1}{c}{ Cabin Creek sub-basin with total basin area 2.35 km } \\
\hline South-facing Alpine Rock & 0.23 & 2387 & 122 & 36 \\
North-facing Alpine Rock & 0.17 & 2379 & 69 & 37 \\
North-facing Alpine Larch/Spruce & 0.02 & 2222 & 60 & 35 \\
South-facing Alpine Larch/Spruce & 0.02 & 2194 & 115 & 32 \\
North-facing Spruce/Fir/Lodgepole Pine & 0.35 & 2046 & 62 & 24 \\
South-facing Spruce/Fir/Lodgepole Pine & 0.93 & 1972 & 151 & 18 \\
Level Spruce/Fir/Lodgepole Pine & 0.05 & 1931 & 0 & 4 \\
Forest Clearings & 0.40 & 1927 & 140 & 11 \\
Level Lodgepole Pine & 0.05 & 1882 & 0 & 3 \\
South-facing Lodgepole Pine & 0.07 & 1798 & 204 & 18 \\
North-facing Lodgepole Pine & 0.01 & 1780 & 76 & 25 \\
Valley Bottom & 0.04 & 1951 & 135 & 18 \\
\hline
\end{tabular}

\begin{tabular}{lccrr}
\hline \multicolumn{4}{c}{ Middle Creek sub-basin with total basin area $2.94 \mathrm{~km}^{2}$} & \\
\hline North-facing Alpine Rock & 0.52 & 2462 & 82 & 31 \\
South-facing Alpine Rock & 1.37 & 2422 & 148 & 30 \\
South-facing Alpine Larch/Spruce & 0.26 & 2246 & 138 & 20 \\
North-facing Alpine Larch/Spruce & 0.08 & 2211 & 46 & 18 \\
North-facing Spruce/Fir/Lodgepole Pine & 0.16 & 1995 & 76 & 21 \\
South-facing Spruce/Fir/Lodgepole Pine & 0.52 & 1953 & 134 & 22 \\
Valley Bottom & 0.03 & 2057 & 115 & 16 \\
\hline \multicolumn{1}{c}{ Twin Creek sub-basin with total basin area $2.79 \mathrm{~km}^{2}$} & & \\
\hline North-facing Alpine Rock & 0.79 & 2386 & 67 & 28 \\
South-facing Alpine Rock & 0.15 & 2380 & 106 & 22 \\
South-facing Alpine Larch/Spruce & 0.28 & 2228 & 116 & 23 \\
North-facing Alpine Larch/Spruce & 0.28 & 2182 & 37 & 22 \\
North-facing Spruce/Fir/Lodgepole Pine & 0.38 & 1966 & 34 & 17 \\
South-facing Spruce/Fir/Lodgepole Pine & 0.36 & 2014 & 113 & 21 \\
North-facing Circular Clearings & 0.26 & 1966 & 34 & 17 \\
South-facing Circular Clearings & 0.24 & 2014 & 113 & 21 \\
Valley Bottom & 0.04 & 1988 & 119 & 16 \\
\hline \multicolumn{1}{c}{ Marmot Confluence sub-basin with total basin area 1.32} & km ${ }^{2}$ & \\
\hline Forest Clearings & 0.01 & 1903 & 55 & 11 \\
North-facing Lodgepole Pine/Aspen & 0.38 & 1786 & 54 & 13 \\
South-facing Lodgepole Pine/Aspen & 0.24 & 1725 & 159 & 13 \\
Level Lodgepole Pine/Aspen & 0.04 & 1688 & 0 & 4 \\
South-facing Lodgepole Pine & 0.44 & 1752 & 172 & 17 \\
Level Lodgepole Pine & 0.02 & 1724 & 0 & 4 \\
North-facing Lodgepole Pine & 0.15 & 1687 & 71 & 14 \\
Valley Bottom & 0.02 & 1664 & 163 & 8 \\
\hline & & & & \\
\hline
\end{tabular}

\subsubsection{Blowing snow parameters}

The values of vegetation density in the alpine taluses and forest HRUs were determined by MacDonald et al. (2010) from field observations and used here; the values of the density for the treeline forest HRUs (i.e. alpine larch/spruce) were estimated from site observations during recent field work. Vegetation heights for alpine taluses and treeline forest HRUs were measured by MacDonald et al. (2010). Based on these measurements, $3 \mathrm{~m}$ was set for the regenerated forest HRU at clearing blocks at Cabin Creek sub-basin, $8 \mathrm{~m}$ was set for the circular forest clearing HRUs at Twin Creek sub-basin 


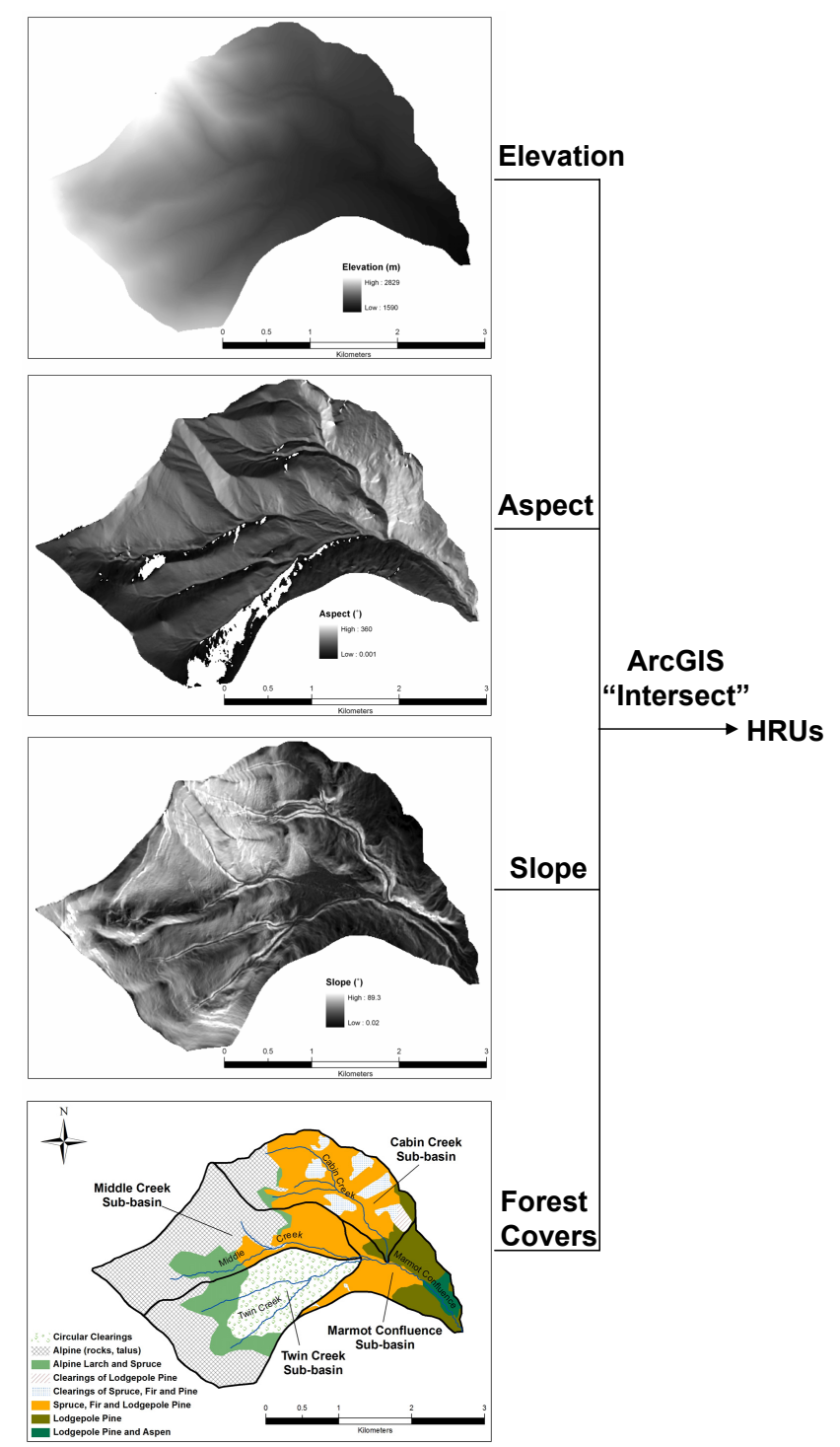

Fig. 5. Pre-processing procedure showing the spatial layers used for generating HRUs in the Marmot Creek Research Basin. A lidar DEM (digital elevation model) and forest cover map provided the information used in this delineation.

and a uniform height of $15 \mathrm{~m}$ was set for the other forest cover HRUs. These heights are the average values for various forest covers and were determined from many site observations. For the blowing snow fetch distance, $300 \mathrm{~m}$ (minimum value) was used for all HRUs in the basin due to the short upwind distance. The blowing snow sequence was decided based on the predominant wind direction in the basin. For Cabin Creek sub-basin, blowing snow initiates from the south-facing alpine talus HRU to the north-facing alpine talus $\mathrm{HRU}$, and snow is redistributed to the north-facing alpine forest HRU and then blown to the south-facing alpine forest HRU where the redistribution of snow ends. For both Middle Creek and Twin Creek sub-basins, snow is transported from the north-facing alpine talus HRU to the south-facing alpine talus HRU, and snow is subsequently redistributed to the south-facing alpine forest HRU, from which snow is blown to the north-facing alpine forest HRU. For other HRUs in the lower elevation part of basin including the mix of spruce, fir, and lodgepole pine HRUs and all HRUs in the Marmot Confluence sub-basin, blowing snow is inconsequential and hence was inhibited in the model.

\subsubsection{Forest snow mass- and energy-balance module parameters}

Effective leaf area index (LAI [-]) was quantified based on measurements from hemispheric images by Ellis et al. (2011), from which average values of 2.07 and 1.44 were estimated for spruce and lodgepole pine forest HRUs. A LAI value of 1.1 was given to alpine forest (i.e. larch) and forest clearings HRUs (i.e. regenerated forest), and this value is similar to the reported values for the forest regeneration (Bewley et al., 2010). For the canopy snow interception capacity, $6.6 \mathrm{~kg} \mathrm{~m}^{-2}$ was assigned to lodgepole pine forest HRU; this is value found for similar forest types (Schmidt and Gluns, 1991; Hedstrom and Pomeroy, 1998). A lower value of $3.3 \mathrm{~kg} \mathrm{~m}^{-2}$ was assigned to the young trees in the forest clearing HRU based on field observation that they cannot intercept snow as effectively as mature trees. A higher value of $8.8 \mathrm{~kg} \mathrm{~m}^{-2}$ was calculated for spruce forest and mixed spruce and lodgepole pine forest HRUs using the method outlined by Ellis et al. (2010). The unloading temperature threshold defines the ice bulb temperature above which intercepted snow starts to unload as either snow or liquid water (i.e. drip). For MCRB, -3 and $6{ }^{\circ} \mathrm{C}$ were set as the temperature thresholds determining when canopy snow is unloaded purely as snow and as meltwater, respectively. Values of unloading temperatures were informed by measurements of a weighed suspended tree and sub-canopy lysimeters that collected unloaded snow from the canopy over several seasons (MacDonald, 2010). For the small circular forest clearings at Twin Creek sub-basin, diameter and surrounding tree height for these clearings were set from the reported values by Golding and Swanson (1986).

\subsubsection{Longwave radiation module parameter}

The terrain view factor parameter was calculated from the sky view factor (i.e. terrain view $=1-$ sky view factor). The sky view factor was measured for the alpine environment by DeBeer and Pomeroy (2009) and was quantified for the subalpine forest environment by Essery et al. (2008) using hemispherical digital photographs.

\subsubsection{Soil infiltration parameters}

To parameterise Gray's parametric infiltration into frozen soils (Zhao and Gray, 1999), initial soil saturation was determined from autumn soil moisture measurements, and initial 
Table 2. Parameters for the hillslope module. soil $l_{\text {rechr_max }}[\mathrm{mm}]$, soil ${ }_{\text {moist_max }}[\mathrm{mm}]$, and $\mathrm{gw}_{\max }[\mathrm{mm}]$ are the water storage capacity for the recharge, soil of both recharge and lower, and groundwater layers, respectively. $K_{\mathrm{S}_{-} \mathrm{gw}}\left[\mathrm{m} \mathrm{s}^{-1}\right], K_{\mathrm{S}_{-} \text {upper }}\left[\mathrm{m} \mathrm{s}^{-1}\right]$ and $K_{\mathrm{S} \_l o w e r}\left[\mathrm{~m} \mathrm{~s}^{-1}\right]$ are the saturated hydraulic conductivity in the groundwater, recharge, and lower of soil layers, respectively. $\lambda[-]$ is the pore size distribution index.

\begin{tabular}{llll}
\hline HRUs & Alpine Rocks/Taluses/Forest & $\begin{array}{l}\text { Subalpine } \\
\text { Forest }\end{array}$ & Confluence \\
\hline soil ${ }_{\text {rechr_max }}$ & 250 & 250 & 250 \\
soil $_{\text {moist_max }}$ & 550 & 425 & 750 \\
gw $_{\text {max }}$ & 500 & 500 & 500 \\
$K_{\text {S_gw }}$ & $6.95 \times 10^{-7}$ & $6.95 \times 10^{-7}$ & $6.95 \times 10^{-7}$ \\
$K_{\text {S_upper }}$ & $2.78 \times 10^{-4} \sim 7.04 \times 10^{-4}$ & $2.78 \times 10^{-4}$ & $2.78 \times 10^{-4}$ \\
$K_{\text {S_lower }}$ & $6.95 \times 10^{-6}$ & $6.95 \times 10^{-6}$ & $6.95 \times 10^{-6}$ \\
$\lambda$ & 2.55 & 2.55 & 2.55 \\
\hline
\end{tabular}

soil temperature was taken from the measured value prior to snowmelt at various hydrometeorological stations in the basin. For the surface saturation, a value of 1 was given due to preferential flow through snowpacks of early meltwater reaching the surface before the start of the main melt period (Marsh and Pomeroy, 1996). Infiltration opportunity time was calculated by the model run using snowmelt rates and snow water equivalent. For the Ayers' infiltration into unfrozen soil (Ayers, 1959), the soil texture parameter was decided by the Marmot Creek soil analysis conducted by Beke (1969), and the surface cover parameter was determined based on the forest cover type from basin and site surveys.

\subsubsection{Hillslope module parameters}

For the soil layers (i.e. recharge and lower layers), the water storage capacity defines the maximum amount of water that can be stored in the soil layers; this was estimated using soil properties such as depth and porosity reported by Beke (1969). For the soil recharge layer corresponding to the shallow top soil layer, $250 \mathrm{~mm}$ (maximum value) was set for all HRUs as the water storage capacity (soil $1_{\text {rechr_max }}[\mathrm{mm}]$ ). The soil water storage capacity of the combined recharge and lower layers (soil moist_max $[\mathrm{mm}]$ ) was estimated as 550 and $425 \mathrm{~mm}$, respectively, for the alpine HRUs (i.e. rocks/taluses and larch forest) and subalpine forest HRUs (i.e. spruce and lodgepole pine), and estimated as $750 \mathrm{~mm}$ for all forest HRUs at Marmot confluence sub-basin. No surface depressions are present in the basin, thus the surface depression capacity $\left(\mathrm{sd}_{\max }[\mathrm{mm}]\right)$ was set to $0 \mathrm{~mm}$. The maximum water storage capacity in the groundwater layer $\left(\mathrm{gw}_{\max }[\mathrm{mm}]\right)$ was estimated as $500 \mathrm{~mm}$ for all HRUs based on previous analysis of the basin hydrogeology (Stevenson, 1967). Values of various water storage capacities are listed in Table 2 and are comparable to, and within the range found in other mountainous environments (Clow et al., 2003; McClymont et al., 2010).
The rates for lateral flow rate in soil layers and groundwater layer (i.e. subsurface and groundwater discharges) as well as vertical flow of excess soil water to groundwater (i.e. groundwater recharge) shown in Fig. 3 are controlled by several drainage factors: rechr $_{\text {ssr_K }}\left[\mathrm{mm} \mathrm{day}^{-1}\right]$, lower ssr_K $_{-}$ $\left[\mathrm{mm} \mathrm{day}^{-1}\right], \mathrm{gw}_{\mathrm{K}}\left[\mathrm{mm} \mathrm{day}^{-1}\right]$ and soil $\mathrm{gw}_{-} \mathrm{K}\left[\mathrm{mm} \mathrm{day}^{-1}\right]$. rechr $_{\text {ssr_K }}$, lower ${ }_{\text {ssr_K }}$ and $\mathrm{gw}_{\mathrm{K}}$ are the drainage factors for lateral flows in soil recharge, lower soil, and groundwater layers, respectively; soil gw_K $_{\text {is }}$ is the drainage factor for the vertical flow from soil to groundwater layer. Previous versions of CRHM had great difficulty in estimating these drainage factors; in the new hillslope module, Darcy's law for unsaturated flow was used to calculate them based on Eq. (1):

$$
\begin{aligned}
v & =K\left(\frac{\Delta h}{\Delta L}\right)=K\left(\frac{\Delta(p / \rho g+z)}{\Delta L}\right)=K\left(\frac{\Delta z}{\Delta L}\right)=K \tan (\theta) & \text { for lateral direction } \\
& =K\left(\frac{\Delta z}{\Delta z}\right)=K & \text { for vertical direction, }
\end{aligned}
$$

where $v\left[\mathrm{~m} \mathrm{~s}^{-1}\right]$ is Darcy's flux (i.e. volume flux per unit area perpendicular to the flow direction), $K\left[\mathrm{~m} \mathrm{~s}^{-1}\right]$ is unsaturated hydraulic conductivity of soil, $\Delta h / \Delta L[-]$ is hydraulic gradient in which $L[\mathrm{~m}]$ is flow path length and $h$ $[\mathrm{m}]$ is hydraulic head, the sum of pressure head $p / \rho g[\mathrm{~m}]$ and elevation $z[\mathrm{~m}]$. For the purpose of estimating Darcy's flux in unconfined flow along steep hillslopes in a mountain basin, the pressure head term is assumed to be inconsequential and hence is neglected. For Darcy's flux in the lateral direction, $\Delta z / \Delta L[-]$ is change of elevation over the flow path length and is approximated by $\tan (\theta)$, where $\theta$ [radian] is the ground slope. For Darcy's flux in the vertical direction, $\Delta z / \Delta L[-]$ becomes $\Delta z / \Delta z[-]$.

In addition, the Brooks and Corey (1964) relationship was used to estimate unsaturated hydraulic conductivity according to Eq. (2):

$$
K=K_{\mathrm{s}} S^{(3+2 / \lambda)},
$$

where $K_{\mathrm{S}}\left[\mathrm{m} \mathrm{s}^{-1}\right]$ is the saturated hydraulic conductivity of soil, $S[-]$ is the saturation of soil, and $\lambda[-]$ is the pore size distribution index. This relationship is well tested and there 
is a large database of information for parameterisation in various environments. The drainage factors needed for CRHM can now be calculated by combining Eqs. (1) and (2):

$$
\begin{aligned}
& \text { rechr }_{\text {ssr_K }}=\mathrm{cK}_{\text {s_upper }} S^{(3+2 / \lambda)} \tan (\theta) \frac{\mathrm{dw}_{\text {unit }}}{A_{\text {unit }}} \\
& =\mathrm{cK}_{\text {s_upper }}\left(\frac{\text { soil }_{\text {rechr }}}{\text { soil }_{\text {rechr_max }}}\right)^{(3+2 / \lambda)} \tan (\theta) \frac{\text { soil }_{\text {rechr_max }}}{1000} \text {, } \\
& \text { lower }_{\text {ssr_K }}=\mathrm{cK}_{\text {s_lower }} S^{(3+2 / \lambda)} \tan (\theta) \frac{\mathrm{dw}_{\text {unit }}}{A_{\text {unit }}} \\
& =\mathrm{cK}_{\text {s_lower }}\left(\frac{\text { soil }_{\text {lower }}}{\text { soil }_{\text {lower_max }}}\right)^{(3+2 / \lambda)} \tan (\theta) \frac{\text { soil }_{\text {lower_max }}}{1000} \\
& \mathrm{gw}_{\mathrm{K}}=\mathrm{cK}_{\mathrm{s}_{\text {_gw }}} \tan (\theta) \frac{\mathrm{dw}_{\text {unit }}}{A_{\text {unit }}}=\mathrm{cK}_{\mathrm{s}_{\text {g gw }}} \tan (\theta) \frac{\mathrm{gw}}{1000} \text {, } \\
& \text { soil }_{\text {gw_K }}=\mathrm{cK}_{\mathrm{s} \_ \text {lower }} S^{(3+2 / \lambda)}=\mathrm{cK}_{\mathrm{s} \_ \text {lower }}\left(\frac{\text { soil }_{\text {moist }}}{\text { soil }_{\text {moist_max }}}\right)^{(3+2 / \lambda)} \text {, }
\end{aligned}
$$

where $K_{\text {S_gw }}\left[\mathrm{m} \mathrm{s}^{-1}\right], K_{\text {s_upper }}\left[\mathrm{m} \mathrm{s}^{-1}\right]$, and $K_{\text {s_lower }}\left[\mathrm{m} \mathrm{s}^{-1}\right.$ ] are the saturated hydraulic conductivities of the groundwater, recharge, and lower of soil layers, respectively. soil rechr $_{\text {r }}$ $[\mathrm{mm}]$ and soil $l_{\text {moist }}[\mathrm{mm}]$ are the storage of water in recharge and entire soil (i.e. recharge and lower layers) layers, respectively; soil $l_{\text {lower }}[\mathrm{mm}]$ is the storage of water in the lower layer and is the difference between soil moist $_{\text {and }}$ soil $1_{\text {rechr }}$, and $c[-]$ is a units conversion factor from $\mathrm{m} \mathrm{s}^{-1}$ to $\mathrm{mm} \mathrm{day}^{-1}$ equal to $86.4 \times 10^{6}$. dw unit $/ A_{\text {unit }}[-]$ is used for converting the Darcy's flux to the drainage factor in which $w_{\text {unit }}$ [m] and $A_{\text {unit }}\left[\mathrm{m}^{2}\right]$ are unit width and unit area, and $d[\mathrm{~m}]$ is the drainage depth in each layer (i.e. soil $1_{\text {rechr_max }}[\mathrm{mm}]$, soil $_{\text {lower_max }}[\mathrm{mm}]$ or $\left.\mathrm{gw}[\mathrm{mm}]\right)$. The maximum values of the water storage capacity in each layer are described above. Values of various saturated hydraulic conductivities and pore size distribution indexes are shown in Table 2 as determined based upon soil texture (Brooks and Corey, 1966; Clapp and Hornberger, 1978). These values are comparable to the findings for similar soil textures (Wallis et al., 1981; Hendry, 1982; Stankovich and Lockington, 1995; Zhang et al., 2010).

\subsubsection{Routing parameters}

The surface and channel flow routing sequences established in CHRM for the MCRB are shown in Fig. 4. In each RB, all non-channel HRUs including alpine rock and forest, other subalpine forests, and forest clearings are routed to the valley bottom HRU. The valley bottom HRU represents a deeply incised gully, and the runoff from this HRU is routed along the main channel in each RB. Then flows from Cabin Creek, Middle Creek, and Twin Creek in the upper part of basin merge into the main stem of Marmot Creek, which subsequently flows out of the basin. Muskingum routing (Chow, 1964) was used for routing of surface flows both within and between RBs as it is a well-established procedure with parameters that can be measured from site visits and DEM extraction, and it incorporates a kinematic wave approximation. For routing between RBs, the routing length is the total length of the main channel in each sub-basin as estimated from the terrain pre-processing GIS analysis using a 2008 lidar DEM. For routing within RBs, the routing length is the mean distance from each HRU to the main channel in each sub-basin, which was estimated from terrain pre-processing in a GIS using the DEM. Manning's equation (Chow, 1959) was used to estimate the average flow velocity, which requires the following parameters: longitudinal channel slope, Manning's roughness coefficient, and hydraulic radius. The longitudinal channel slope of a HRU or a sub-basin was estimated from the average slope of the corresponding HRU or sub-basin, which was derived from the terrain pre-processing GIS analysis using the 2008 lidar DEM. Manning's roughness coefficient was assigned based on surface cover and channel condition using a Manning's roughness lookup table (Mays, 2001). The hydraulic radius was determined from the lookup table using channel shape and depth of channel as criteria; channel shape was set as parabolic as determined from field observation, and channel depth was measured in the field. The flow travel time was calculated from the routing length and average flow velocity. The dimensionless weighting factor controls the level of attenuation, ranging from 0 (maximum attenuation) to 0.5 (no attenuation), and can be determined by a number of techniques (Wu et al., 1985; Kshirsagar et al., 1995). However, information for approximating this parameter is lacking, so a medium value of 0.25 was assigned for the basin.

For subsurface and groundwater flows, Clark's lag and route algorithm (Clark, 1945) was used. The travel time parameter for subsurface and groundwater flows was calculated from basin characteristics using a method based on effective porosity, soil hydraulic conductivity, routing length, and average bedrock slope (Henderson and Wooding, 1964; Sabzevari et al., 2010). Both effective porosity and soil hydraulic conductivity were determined according to soil texture. Routing length for subsurface and groundwater flows was assumed to be the same as routing length of surface runoff, and bedrock slope was assumed to have the same value as surface slope.

\section{Evaluations for model simulations}

Model simulations of snow accumulation, springtime snowmelt, soil moisture, streamflow, and groundwater storage were conducted in the MCRB for six hydrological years (i.e. 1 October to 30 September) from 2005 to 2011, for which good measurements to run and evaluate the model existed. Simulated hydrological variables were evaluated against available observations of snow accumulation, snowmelt, soil moisture, streamflow, and groundwater level. To assess the performance of model, five statistical indexes - root mean square difference (RMSD), normalised RMSD (NRMSD), model bias (MB), Nash-Sutcliffe efficiency (NSE) (Nash and Sutcliffe, 1970), and Pearson 

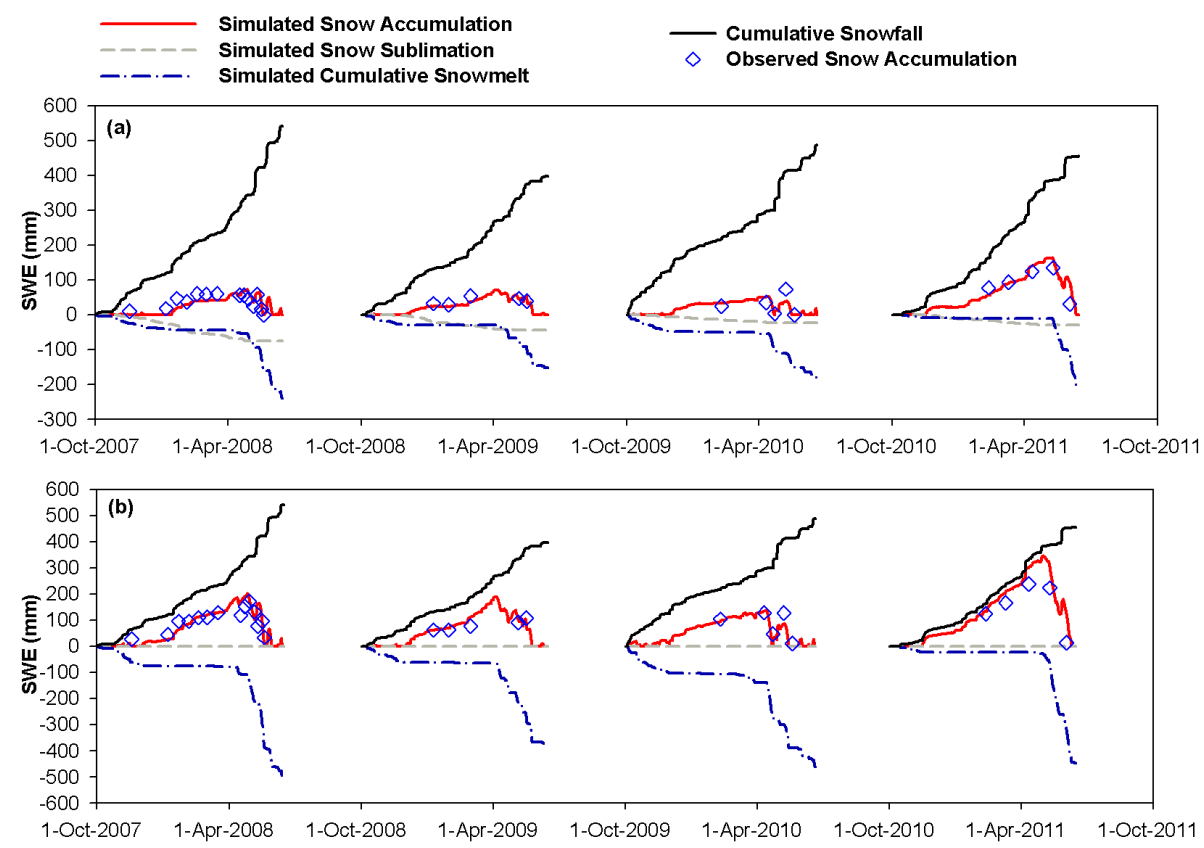

Fig. 6. Comparisons of the observed and simulated snow accumulation (SWE) for 2007-2011 at the sheltered, mid-elevation Upper Forest and Upper Clearing sites in the MCRB. (a) Mature spruce forest and (b) forest clearings.

product-moment correlation coefficient $(r)$ were calculated as follows:

$$
\begin{aligned}
& \mathrm{RMSD}=\sqrt{\frac{1}{n} \sum\left(X_{\mathrm{s}}-X_{\mathrm{o}}\right)^{2}}, \\
& \mathrm{NRMSD}=\frac{\mathrm{RMSD}}{\overline{X_{\mathrm{o}}}}, \\
& \mathrm{MB}=\frac{\sum X_{\mathrm{s}}}{\sum X_{\mathrm{o}}}-1, \\
& \mathrm{NSE}=1-\frac{\sum\left(X_{\mathrm{o}}-X_{\mathrm{s}}\right)^{2}}{\sum\left(X_{\mathrm{o}}-\overline{X_{\mathrm{o}}}\right)^{2}}, \\
& r=\frac{\sum\left(X_{\mathrm{o}}-\overline{X_{\mathrm{o}}}\right)\left(X_{\mathrm{s}}-\overline{X_{\mathrm{S}}}\right)}{\sqrt{\sum\left(X_{\mathrm{o}}-\overline{X_{\mathrm{o}}}\right)^{2} \sum\left(X_{\mathrm{s}}-\overline{X_{\mathrm{s}}}\right)^{2}}},
\end{aligned}
$$

where $n$ is number of samples, and $X_{\mathrm{o}}, X_{\mathrm{s}}, \overline{X_{\mathrm{o}}}$ and $\overline{X_{\mathrm{s}}}$ are the observed, simulated, mean of the observed, and mean of simulated values, respectively. The RMSD is a weighted measure of the difference between observation and simulation and has the same units as the observed and simulated values, while NRMSD is the RMSD normalised against the mean of the observed values. The MB indicates the ability of model to reproduce the measured variable; a positive value or a negative value of MB implies model overprediction or underprediction, respectively. The NSE is a measure for model efficiency to reproduce the time evolution of hydrological variables and is particularly appropriate for evaluating streamflow hydrograph prediction (Nash and Sutcliffe, 1970). A NSE value equal to 1 indicates perfect model predictions with respect to observations; a value equal to 0 implies that estimated values are not different from the average of observed values. Thus, any positive value of NSE suggests that model has some predictive power with higher values indicating progressively better model performance. The Pearson coefficient $r$ ranges from -1 to 1 and measures the correlation between two variables, with positive and negative values indicating that two variables are positively and negatively correlated, respectively.

\subsection{Snow accumulation and snowmelt evaluation}

Predictions of snow accumulation (SWE) for specific HRUs were compared to corresponding SWE determinations from extensive surveys of snow depth and density of same HRUs in the MCRB. Model evaluations were conducted at subalpine mature spruce forest and clearings sites (i.e. Upper Forest and Upper Clearing) as well as at alpine larch forest, ridge top, and north- and south-facing slopes near Fisera Ridge for the pre-melt accumulation and ablation periods of 2007-2011. Figure 6 shows the observed and predicted SWE over the snow courses at the relatively sheltered Upper Forest and Upper Clearing sites, while Fig. 7 illustrates the observations and simulations of SWE at various locations at the windblown Fisera Ridge site. The results demonstrate that the model was able to simulate the SWE regime in both subalpine and alpine environments. Exceptions were found for south-facing slope and larch forest HRUs during the season of 2009/2010 (Fig. 7c-e) where SWE was overestimated. This may have been due to exceptional wind directions or flow separation causing a different blowing snow 


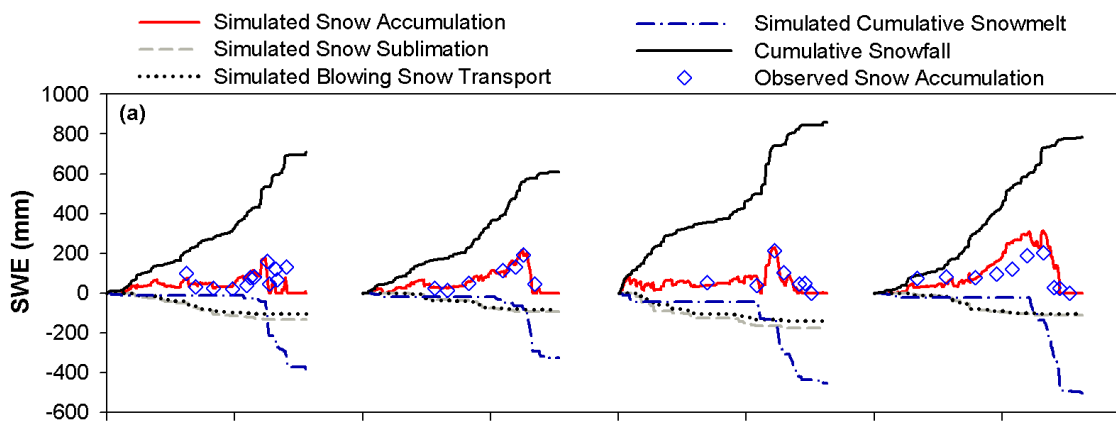

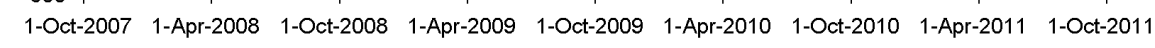

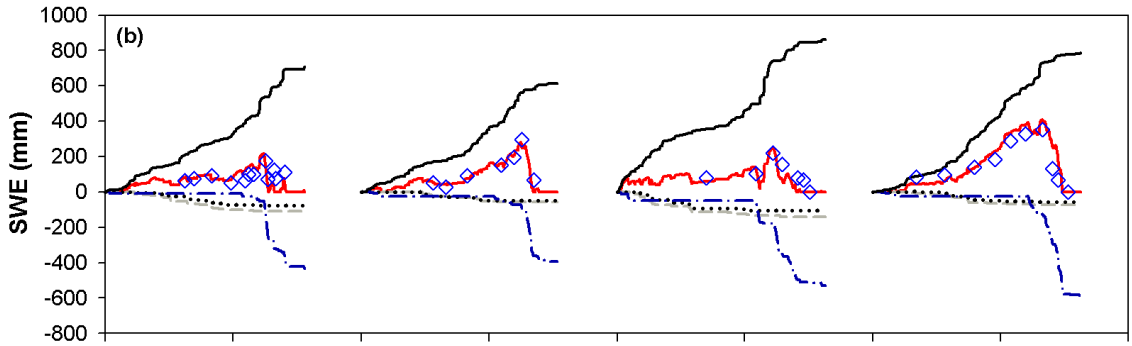

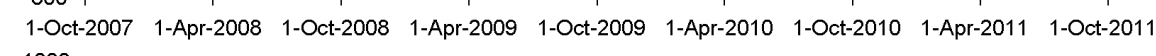

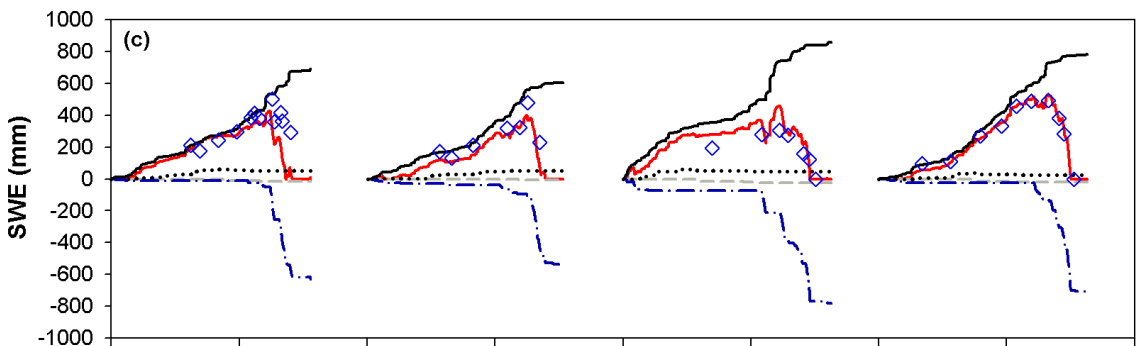

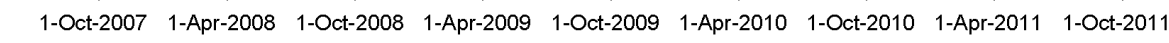

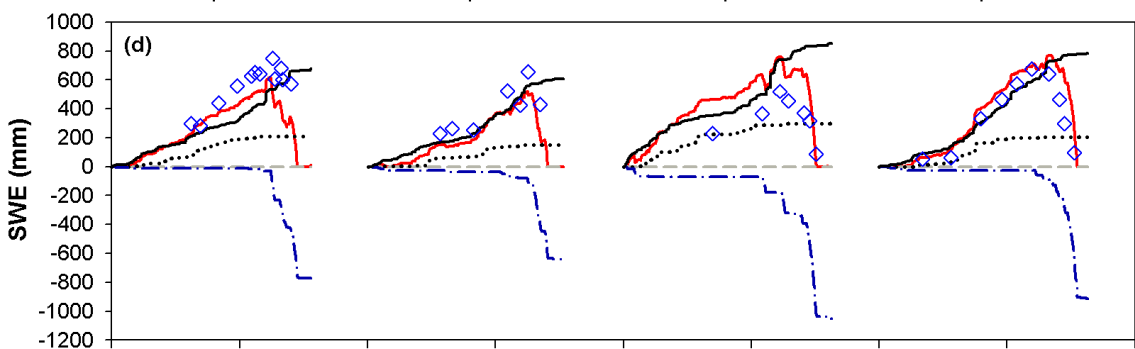

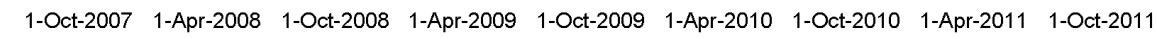

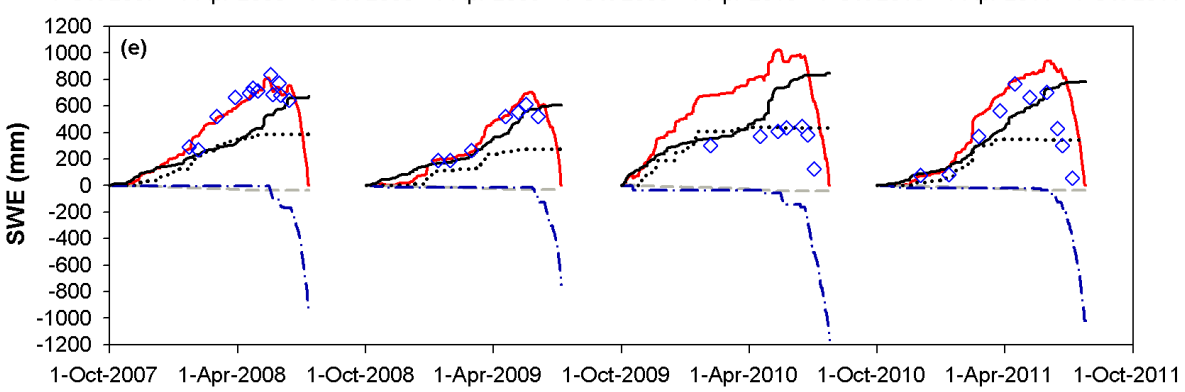

Fig. 7. Comparisons of the observed and simulated snow accumulation (SWE) for 2007-2011 at the wind-blown, high-elevation Fisera Ridge in the MCRB. (a) North-facing slope, (b) ridge top, (c) top south-facing slope, (d) bottom south-facing slope, and (e) larch forest. 
Table 3. Evaluation of simulated snow accumulations via the root mean square difference (RMSD, mm SWE), normalised RMSD (NRMSD), and model bias (MB) at Upper Forest/Clearing and Fisera Ridge sites, Marmot Creek Research Basin during seasons from 2007 to 2011.

\begin{tabular}{|c|c|c|c|c|c|c|c|}
\hline & \multicolumn{2}{|c|}{ Upper Forest/Clearing } & \multicolumn{5}{|c|}{ Fisera Ridge } \\
\hline & $\begin{array}{l}\text { Spruce } \\
\text { Forest }\end{array}$ & $\begin{array}{r}\text { Forest } \\
\text { Clearings }\end{array}$ & $\begin{array}{r}\text { North-facing } \\
\text { Slope }\end{array}$ & $\begin{array}{r}\text { Ridge } \\
\text { Top }\end{array}$ & $\begin{array}{l}\text { Top South- } \\
\text { facing Slope }\end{array}$ & $\begin{array}{l}\text { Bottom South- } \\
\text { facing Slope }\end{array}$ & $\begin{array}{l}\text { Larch } \\
\text { Forest }\end{array}$ \\
\hline \multicolumn{8}{|c|}{ RMSD } \\
\hline $2007 / 2008$ & 16.2 & 33.8 & 50.5 & 52.1 & 127.6 & 170.5 & 58.0 \\
\hline $2008 / 2009$ & 9.5 & 17.0 & 19.3 & 30.6 & 76.0 & 125.5 & 56.4 \\
\hline $2009 / 2010$ & 17.7 & 28.7 & 35.0 & 53.5 & 76.9 & 213.3 & 499.3 \\
\hline 2010/2011 & 32.5 & 74.5 & 77.9 & 65.8 & 21.9 & 144.6 & 302.2 \\
\hline All seasons & 19.4 & 41.2 & 53.3 & 53.3 & 88.4 & 165.5 & 274.9 \\
\hline \multicolumn{8}{|c|}{ NRMSD } \\
\hline $2007 / 2008$ & 0.41 & 0.34 & 0.68 & 0.57 & 0.38 & 0.31 & 0.09 \\
\hline $2008 / 2009$ & 0.24 & 0.21 & 0.24 & 0.24 & 0.28 & 0.32 & 0.14 \\
\hline 2009/2010 & 0.65 & 0.35 & 0.49 & 0.53 & 0.40 & 0.64 & 1.42 \\
\hline 2010/2011 & 0.35 & 0.49 & 0.88 & 0.39 & 0.08 & 0.40 & 0.75 \\
\hline All seasons & 0.42 & 0.40 & 0.67 & 0.44 & 0.31 & 0.39 & 0.59 \\
\hline \multicolumn{8}{|c|}{$\mathrm{MB}$} \\
\hline $2007 / 2008$ & -0.07 & 0.06 & -0.28 & -0.14 & -0.26 & -0.27 & 0.00 \\
\hline $2008 / 2009$ & -0.10 & 0.10 & 0.01 & -0.10 & -0.23 & -0.27 & 0.09 \\
\hline $2009 / 2010$ & -0.11 & -0.24 & -0.20 & -0.28 & 0.28 & 0.57 & 1.41 \\
\hline 2010/2011 & 0.17 & 0.42 & 0.53 & 0.22 & 0.01 & 0.31 & 0.57 \\
\hline All seasons & 0.004 & 0.12 & 0.04 & -0.015 & -0.11 & -0.006 & 0.36 \\
\hline
\end{tabular}

regime from the constant redistribution sequence and flow direction parameterised in the model. Figures also show simulations of major snow-related processes (e.g. snow interception and sublimation from forest canopy, transport and sublimation from blowing snow for alpine environment), which demonstrates contribution of parameterisation for these processes to the overall agreement between the model simulated and observed snow accumulation.

Table 3 shows the RMSD for SWE predictions over four snow seasons during the period 2007-2011, which were 19.4 and $41.2 \mathrm{~mm}$ for the mature spruce forest and forest clearings HRUs, respectively. These relatively small values of RMSD for the subapline needleleaf forest indicate that model was able to simulate the major snow hydrological processes (e.g. forest snow interception and sublimation, extinction of shortwave and enhanced longwave radiation under canopy, and other energetics for snowmelt) that are controlled and influenced by the forest canopy. The alpine environment at Fisera Ridge had relatively larger RMSD values for all four seasons, ranging from 53.3 to $274.9 \mathrm{~mm}$, but considering the larger mean SWE in the alpine, NRMSD ranged only from 0.31 to 0.67 , meaning that RMSD ranged from 31 to $67 \%$ of mean seasonal observed snow accumulations. The large values of all seasons RMSD found for bottom south-facing and larch forest HRUs (i.e. 165.5 and $274.9 \mathrm{~mm}$ ) are mostly caused by overestimations for the single season of 2009/2010 with seasonal RMSD of 213.3 and
$499.3 \mathrm{~mm}$. Nonetheless, the model simulated the dominant hydrological process in the alpine environment (i.e. blowing snow) as snow was correctly redistributed from the source area HRU (e.g. north-facing slope and ridge top) to the sink area HRU (e.g. south-facing slope and larch forest) as depicted in Fig. 7. Table 3 also shows values of MB for SWE predictions over four snow seasons during the period 20072011; all seasons MB ranged from -0.006 to 0.36 . This implies that SWE predictions ranged from $0.6 \%$ underestimation for the bottom south-facing slope HRU at Fisera Ridge to $36 \%$ overestimation for the larch forest HRU at Fisera Ridge over four snow seasons, while overestimations were 0.4 and $12 \%$ for the mature spruce forest and forest clearings HRUs, respectively.

In most cases the timing of snowmelt and snow depletion matched observations, as seen in Figs. 6 and 7. The mean difference in peak snow accumulation between simulation and observation ranged from 2.4 to $16 \%$ for the Upper Forest and Upper Clearing sites and from 1.6 to $29 \%$ for the Fisera Ridge site. The peak snow accumulation determines the snow water available for infiltration and runoff and so this statistic is extremely important in assessing the hydrological predictive capability of the model. 

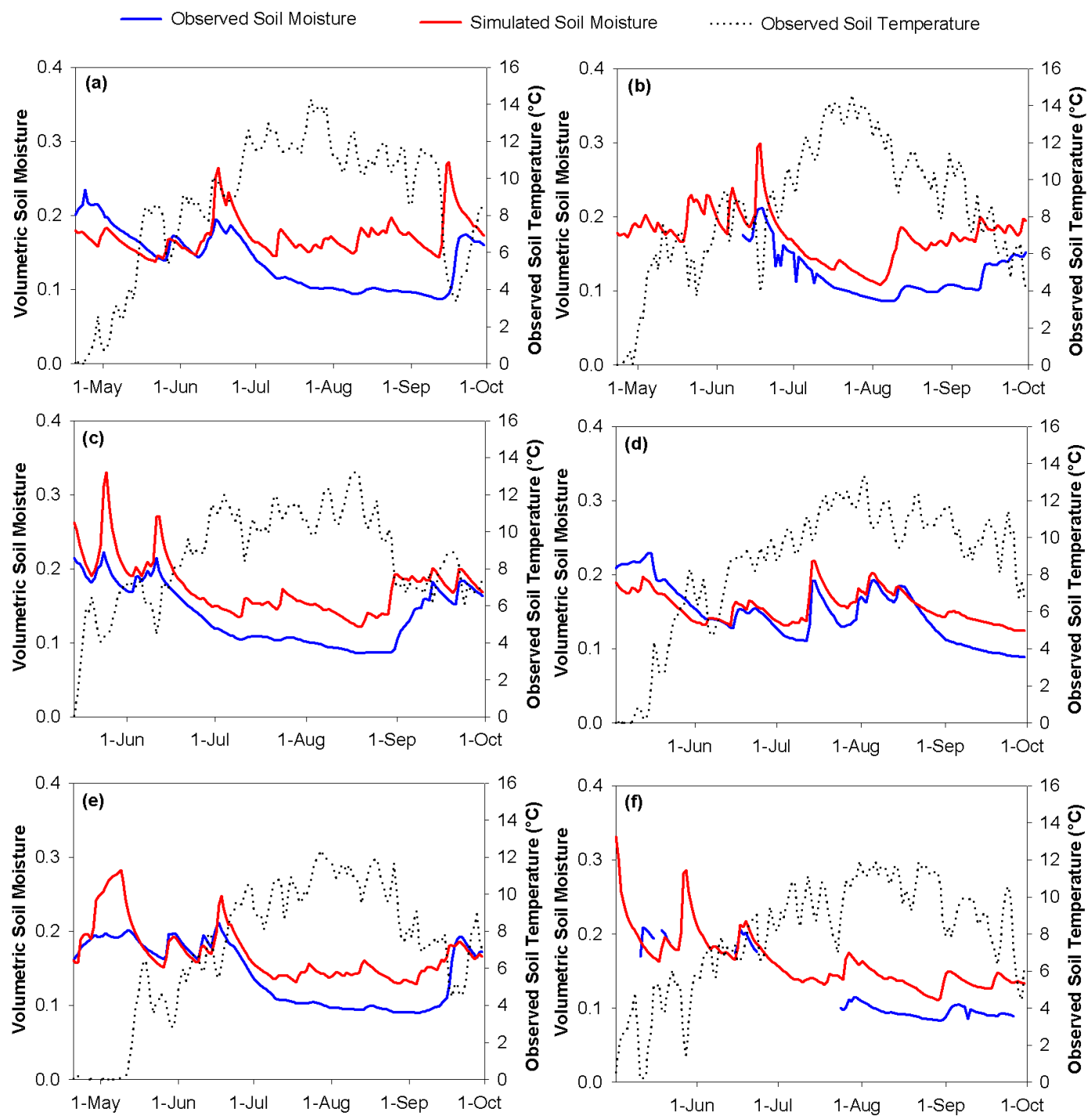

Fig. 8. Comparisons of the observed and simulated seasonal daily volumetric soil moisture at Level Forest in the MCRB. (a) 2006, (b) 2007, (c) 2008, (d) 2009, (e) 2010, and (f) 2011. Note that comparisons are valid only when the observed soil temperature is above $0{ }^{\circ} \mathrm{C}$.

\subsection{Soil moisture evaluation}

Simulations of recharge layer soil moisture conducted for the mature lodgepole pine site (i.e. Level Forest) at Marmot Creek were compared to observations of seasonal soil moisture (i.e. 1 April to 30 September) during the period 2006-2011. The simulated recharge layer corresponds to the top $50 \mathrm{~cm}$ of soil, while the observation is the top $25 \mathrm{~cm}$ of soil, so it is the pattern of change, rather than soil moisture magnitudes that should be compared. Figure 8 shows the observed and simulated daily volumetric soil moisture for Level Forest site for the non-frozen period as reported by the CS616 soil water content probes at the site. The predicted temporal patterns of soil moisture recharge and discharge generally matched observations with peaks in spring and early summer after soil thaw and were associated with rain or snowmelt. After soil thaw, the predicted soil moisture magnitudes matched observations closely in spring but overestimated consistently in the summer months. The summer overestimation may have been due to the measurement depth $(0-25 \mathrm{~cm})$ being above much of the model layer depth $(0$ $50 \mathrm{~cm}$ ) and hence due to root withdrawal of water for transpiration, or due to the model overestimating infiltration in summer. Given that the porous forest soils in Marmot Creek generally have infiltration rates far in excess of rainfall rates (Beke, 1969) and that the model permitted high infiltration rates, an overestimation of infiltration is unlikely and the difference is more likely due to the different layer depths. These results suggest that the model has some capability of simulating the many hydrological processes (e.g. infiltration of both snowmelt and rainfall, evapotranspiration, drainage) controlling soil moisture fluctuation in the lodgepole forest 

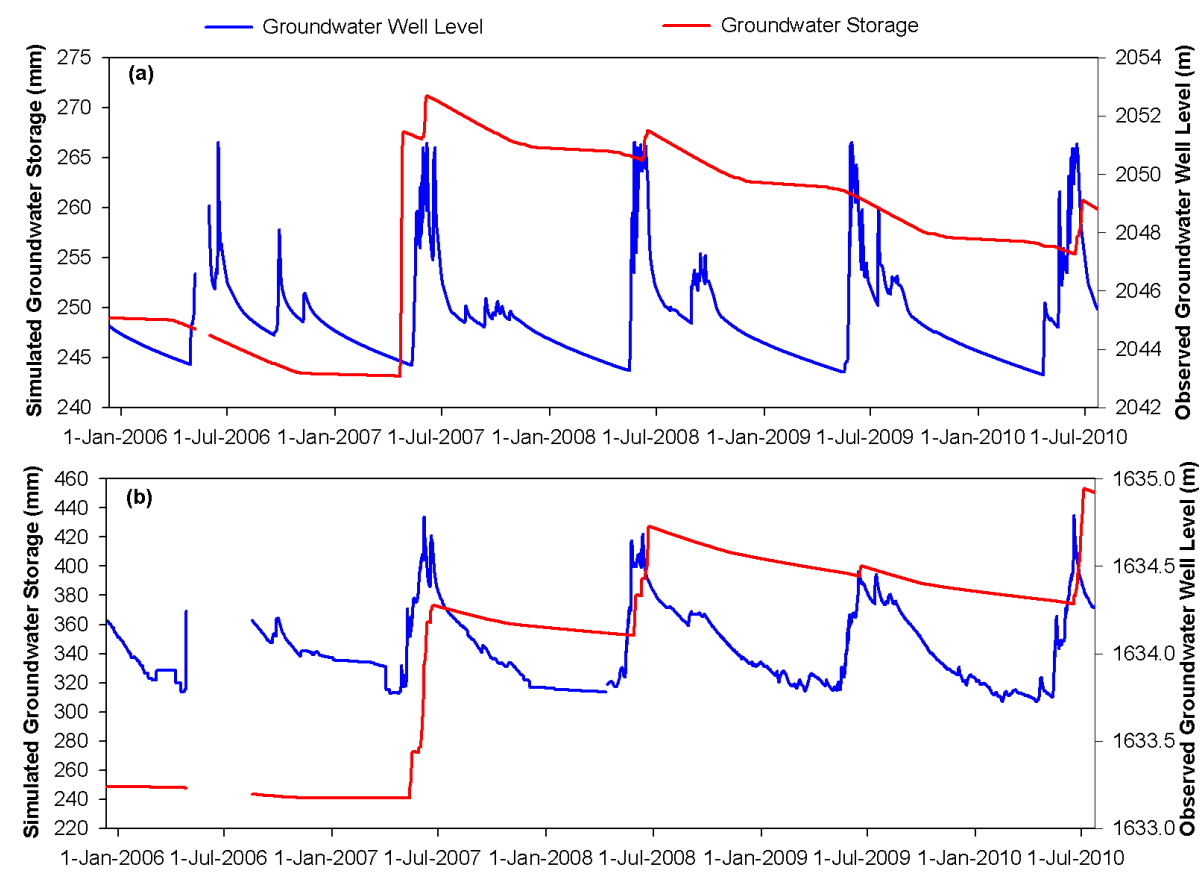

Fig. 9. Comparisons of the observed hourly groundwater level fluctuation and simulated hourly groundwater storage during the period 13 December 2005-21 July 2010. (a) Well GW305 and (b) well GW386.

environments at Marmot Creek. This capability is quantified in Table 4, which shows the calculated RMSD for the simulated seasonal daily volumetric soil moisture in each season for the period 2006-2011. RMSD values ranged from 0.025 to 0.055 for the simulations at the Level Forest site, suggesting that, on average, the difference between the observed and simulated volumetric soil moisture was between 2.5 to $5.5 \%$ volumetric water content. However, the NRMSD ranged only from 0.17 to 0.39 , which indicates that RMSD is a relatively large portion of the simulated value, being equal to 17 to $39 \%$ of seasonal mean observed volumetric soil moisture. The MB ranged from 0.07 to 0.34 , implying that the model tended to overpredict the seasonal soil moisture; however, overestimations were less than $34 \%$ and are likely due to the soil moisture probes measuring only a shallow soil layer rather than the simulated soil layer.

\subsection{Groundwater evaluation}

Simulated groundwater storage was assessed by comparing to the observed groundwater level at two groundwater wells (i.e. GW305 and GW386) that were available from Alberta Environment over the period 13 December 200521 July 2010 . The hourly groundwater storage was estimated for the groundwater water layer located around these two wells and was compared to the observed hourly groundwater level fluctuation (Fig. 9). The figure demonstrates that the seasonal pattern (i.e. increase and decrease) in groundwater storage partly followed the pattern (i.e. rise and decline) of groundwater level except for the seasons of 2006
Table 4. Evaluation of the simulated seasonal volumetric soil moisture via the root mean square difference (RMSD, $\mathrm{mm} \mathrm{mm}^{-1}$ ), normalised RMSD (NRMSD), and model bias (MB) at Level Forest site, Marmot Creek Research Basin.

\begin{tabular}{cccc}
\hline & RMSD & NRMSD & MB \\
\hline 2006 & 0.055 & 0.39 & 0.25 \\
2007 & 0.048 & 0.39 & 0.34 \\
2008 & 0.046 & 0.33 & 0.27 \\
2009 & 0.025 & 0.17 & 0.07 \\
2010 & 0.037 & 0.26 & 0.19 \\
2011 & 0.040 & 0.35 & 0.28 \\
\hline
\end{tabular}

and 2009, while the seasonal peak in groundwater storage fell behind the seasonal peak in groundwater level hydrograph. Pearson product-moment correlation coefficients of 0.15 and 0.17 were calculated for the correlations between groundwater storage and level for GW305 and GW386 during the period 13 December 2005-21 July 2010, respectively. These low positive correlation coefficient values indicate a weak positive correlation between the groundwater storage and well level. The low values are attributed to delayed simulated groundwater storage corresponding to groundwater level in three seasons (i.e. 2007, 2008, and 2010) and pattern of simulated groundwater storage mismatching the groundwater level in two seasons (i.e. 2006 and 2009). The simplified groundwater routing module in CRHM clearly does not have the capability to accurately simulate complex 
groundwater interactions, but does show some aspects of seasonal recharge and the drawdown that is important for calculating baseflow contributions to streamflow discharge.

\subsection{Streamflow evaluation}

Streamflow simulations conducted for the sub-basins of Cabin Creek, Middle Creek and Twin Creek were compared to the gauged discharges at the outlets of the three sub-basins. These simulations provide information on the sub-basin scale integration of all surface and subsurface hydrological processes that contribute to runoff generation. The gauging period usually extended from May to September during the years 2007-2011; gauging started when the channels were choked with deep snow in the spring, and ceased when ice cover formed in the autumn. Because of snow and ice in the channels, there is great uncertainty in some of the early season estimates of stream stage and velocity. Streamflow simulations for the entire basin were evaluated using Water Survey of Canada gauged discharges on Marmot Creek, from 1 May to 30 September during the years 2006-2011. These stage and velocity observations follow WMO standards and use a v-notch weir which is considered very reliable. The Marmot Creek discharge is a composite of discharge from the upper sub-basins and also local inflows in the lower basin, so it indicates the operation of runoff processes and streamflow routing at a much larger scale than for the sub-basins. Figure 10 shows the comparisons of observed and predicted daily streamflow discharge for Cabin Creek, Middle Creek, Twin Creek, and Marmot Creek. Simulations of the daily discharge for the upper three sub-basins over the five-season period (i.e. 2007-2011) were often in close agreement with gauged discharges; however, simulated peak discharges were greater than those gauged in 2007, 2008, and 2009 for Cabin Creek, 2010 and 2011 for Middle Creek, and 2008 for Twin Creek. While simulated peak discharge was smaller than the gauged peak discharge in 2009 for Middle and Twin creeks, simulations for other years were close to gauged results. The timing of peak discharge was poorly simulated in 2008 for all sub-basins and 2009 and 2011 for Twin Creek, but simulations were much better in 2007 and 2010 for all subbasins, and in 2009 and 2011 for Cabin and Middle creeks (Fig. 10a-c). Table 5 lists the calculated NSE of $0.28,0.2$, and 0.23 for the simulated discharge at Cabin Creek, Middle Creek, and Twin Creek over the five-season period, respectively. This suggests that the model had the capability to reproduce aspects of the time-series evolution of discharge from these sub-basins, although the capability is not high and there were negative seasonal NSE in 2008 for Cabin Creek and 2009 for all sub-basins. Nevertheless, on average, the difference between the daily simulated and observed discharge was relatively small for these sub-basins, with a five-season RMSD ranging from 0.036 to $0.096 \mathrm{~m}^{3} \mathrm{~s}^{-1}$ shown in Table 5; the five-season NRMSD ranged from 0.72 to 0.76 . The MB listed in Table 5 over the five-season period for these
Table 5. Evaluation of the simulated daily mean streamflow discharge for Cabin Creek, Middle Creek, Twin Creek, and Marmot Creek using the Nash-Sutcliffe efficiency (NSE), root mean square difference (RMSD, $\mathrm{m}^{3} \mathrm{~s}^{-1}$ ), normalised RMSD (NRMSD), and model bias (MB).

\begin{tabular}{|c|c|c|c|c|}
\hline & $\begin{array}{l}\text { Cabin } \\
\text { Creek }\end{array}$ & $\begin{array}{r}\text { Middle } \\
\text { Creek }\end{array}$ & $\begin{array}{r}\text { Twin } \\
\text { Creek }\end{array}$ & $\begin{array}{r}\text { Marmot } \\
\text { Creek }\end{array}$ \\
\hline \multicolumn{5}{|c|}{ NSE } \\
\hline 2006 & & & & 0.62 \\
\hline 2007 & 0.77 & 0.54 & 0.66 & 0.69 \\
\hline 2008 & -2.08 & & 0.08 & 0.48 \\
\hline 2009 & -0.05 & -0.03 & -0.05 & 0.58 \\
\hline 2010 & 0.22 & 0.10 & 0.41 & 0.45 \\
\hline 2011 & 0.36 & 0.22 & 0.18 & 0.56 \\
\hline All seasons & 0.28 & 0.20 & 0.23 & 0.58 \\
\hline \multicolumn{5}{|c|}{ RMSD } \\
\hline 2006 & & & & 0.116 \\
\hline 2007 & 0.029 & 0.064 & 0.071 & 0.164 \\
\hline 2008 & 0.069 & & 0.128 & 0.161 \\
\hline 2009 & 0.023 & 0.107 & 0.103 & 0.095 \\
\hline 2010 & 0.034 & 0.086 & 0.075 & 0.136 \\
\hline 2011 & 0.035 & 0.091 & 0.102 & 0.189 \\
\hline All seasons & 0.036 & 0.088 & 0.096 & 0.147 \\
\hline \multicolumn{5}{|c|}{ NRMSD } \\
\hline 2006 & & & & 0.60 \\
\hline 2007 & 0.47 & 0.58 & 0.43 & 0.54 \\
\hline 2008 & 1.64 & & 0.54 & 0.60 \\
\hline 2009 & 0.51 & 0.70 & 0.72 & 0.48 \\
\hline 2010 & 0.95 & 0.70 & 0.82 & 0.66 \\
\hline 2011 & 0.65 & 0.86 & 0.99 & 0.65 \\
\hline All seasons & 0.76 & 0.72 & 0.75 & 0.60 \\
\hline \multicolumn{5}{|c|}{$\mathrm{MB}$} \\
\hline 2006 & & & & -0.02 \\
\hline 2007 & 0.05 & -0.10 & -0.26 & -0.05 \\
\hline 2008 & 1.09 & & -0.45 & 0.09 \\
\hline 2009 & -0.04 & -0.46 & -0.42 & 0.12 \\
\hline 2010 & 0.21 & -0.38 & -0.18 & 0.06 \\
\hline 2011 & 0.27 & -0.01 & -0.06 & -0.08 \\
\hline All seasons & 0.21 & -0.27 & -0.29 & 0.01 \\
\hline
\end{tabular}

sub-basins ranged from -0.29 to 0.21 , indicating that the predicted total discharge from the five seasons varied from a $29 \%$ underestimation for Twin Creek sub-basin to a $21 \%$ overestimation for Cabin Creek sub-basin and therefore was neither consistently over nor underestimated. There are several possible reasons for the modest predictive capability of the model at the sub-basin scale. The first is the uncertainty in the gauged discharges from natural channel reaches, which in spring were under snow and ice. The second and more likely contributor to the differences between model and gauged discharge is that certain small-scale transient processes such as 

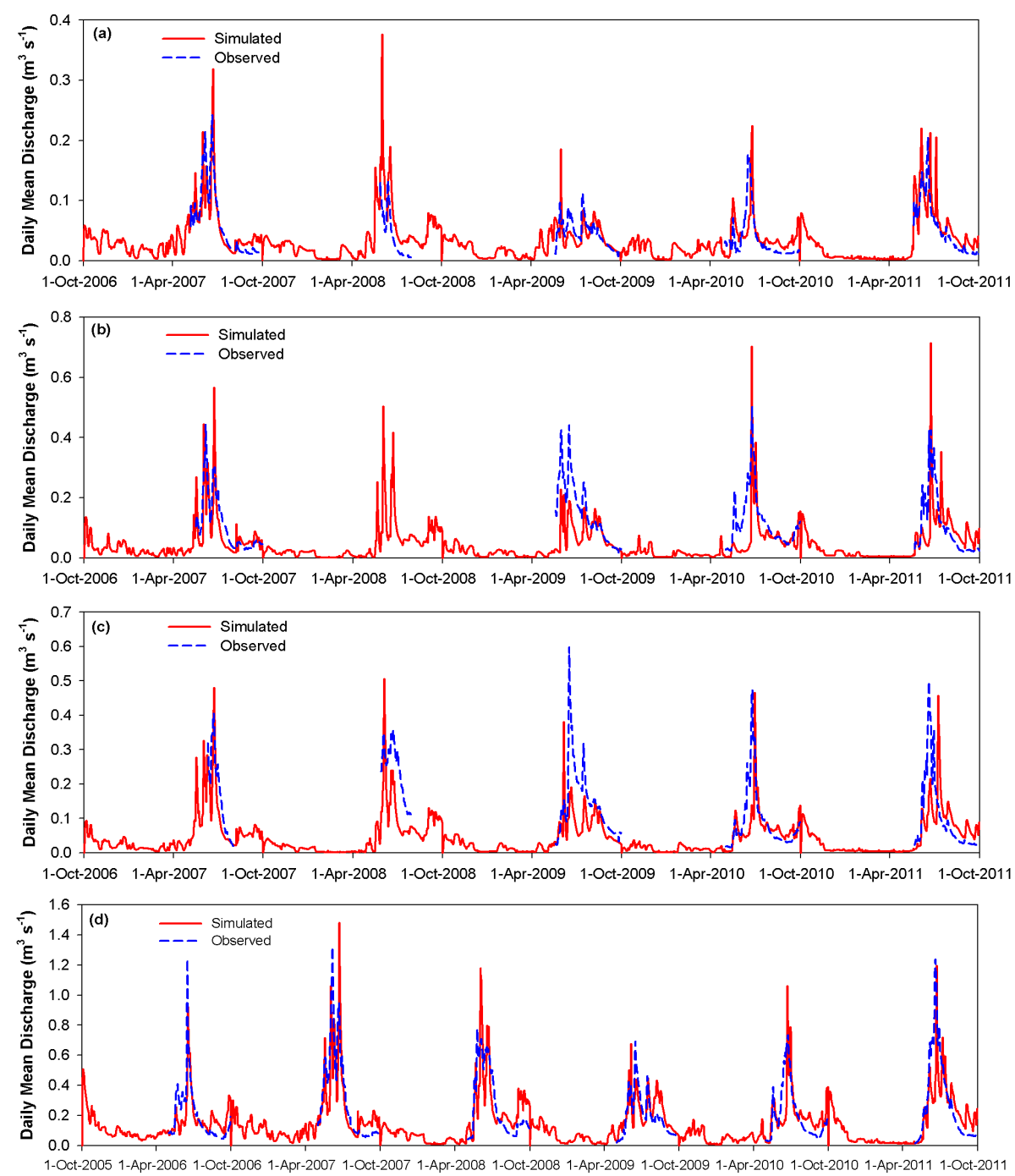

Fig. 10. Comparisons of observed and simulated daily streamflow for 2005-2011 at the outlets of (a) Cabin Creek, (b) Middle Creek, (c) Twin Creek, and (d) Marmot Creek. Note that streamflow observations for Cabin, Middle, and Twin creeks started in spring 2007 and no measurements were available for Middle Creek in 2008 due to disturbance from wildlife.

temporary snow damming and subsequent upstream water storage and release in snow-choked channels could not be adequately represented using a Muskingum routing procedure. Other contributors to the differences between model and simulation are processes such as subsurface storage and runoff on hillslopes were simulated using a relatively simple threelayer model with great uncertainty as to appropriate subsurface velocities for kinematic wave routing within the HRU. Since the sub-basins were relatively small $\left(2.35\right.$ to $\left.2.79 \mathrm{~km}^{2}\right)$ and were composed of relatively few HRU (7 to 12), precise hillslope routing within the HRU is important to correctly generate the sub-basin hydrograph, and an error in the hillslope routing from any one HRU could potentially make a great contribution to the error in the hydrograph. In addition, the model was not calibrated in any way to fit the hydrograph and so presumably calibration of uncertain hillslope routing and other subsurface parameters would lead to improved model performance.

The model performed much better in predicting streamflow discharge for the Marmot Creek basin outlet compared to the simulations of streamflow discharge for the sub-basins. Figure 10d illustrates that the simulated daily discharge hydrograph over the six-season period (i.e. 2006-2011) was quite comparable to the observed, with closer estimations of magnitude and timing of peak discharge than simulations for the sub-basins. Table 5 shows seasonal NSE ranged from 0.45 in 2010 to 0.69 in 2009, with six-season NSE equal to 0.58 for simulated discharge at the Marmot Creek basin outlet, indicating that the model was capable of reproducing the temporal evolution of daily discharge for the entire basin in this period. In addition, Table 5 demonstrates that six-season RMSD and MB were $0.147 \mathrm{~m}^{3} \mathrm{~s}^{-1}$ and 0.01 , 

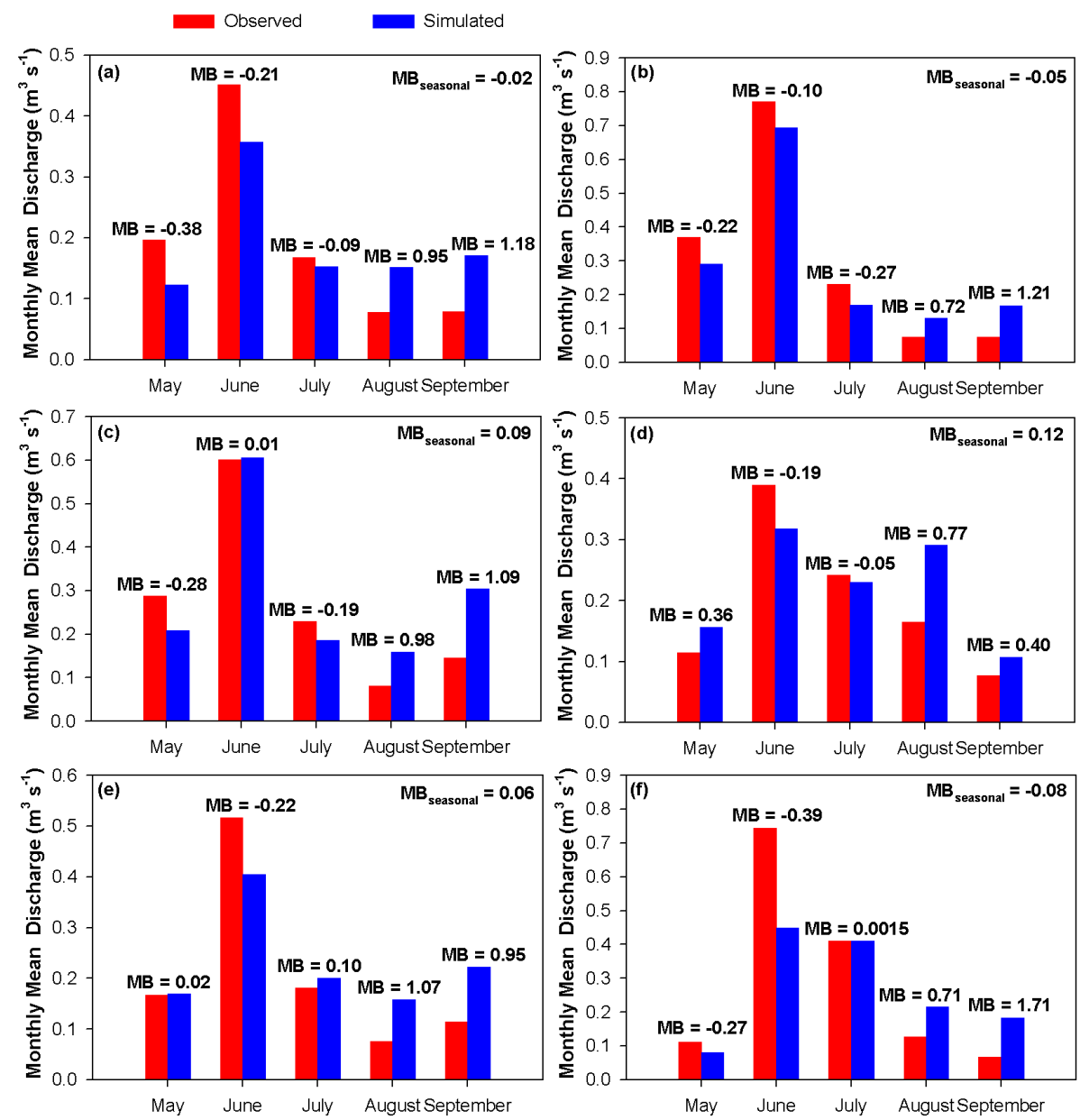

Fig. 11. Comparisons of observed and simulated monthly streamflow at the outlet of Marmot Creek during (a) 2006, (b) 2007, (c) 2008, (d) 2009, (e) 2010, and (f) 2011.

respectively, for the simulation of daily discharge at Marmot Creek basin. This means, on average, the difference between the observation and simulation of Marmot Creek basin daily discharge was quite small, with only a $1 \%$ overestimation for the cumulative discharge in the six-season period. The improvement in prediction for Marmot Creek compared to its sub-basins is likely due to the spatial implementation of the model with 36 HRUs for Marmot Creek but 12 or less HRUs for any individual sub-basin and to the emergence of streamflow routing as an important factor in hydrograph generation for the $9.4 \mathrm{~km}^{2}$ basin. The Muskingum streamflow routing of flow to the Water Survey of Canada gauge is likely to be more accurate than that to the sub-basin gauges as snow-choked channels are restricted to the higher elevations in the basin and the channel characteristics in the lower basin are well understood and likely better parameterised in the model. Since calibration of model parameters was not used, model performance is very sensitive to the level of understanding of basin physiography and hydraulic characteristics, which is generally better at lower elevations near the main stream gauge.
Modelled monthly discharges at the outlet of Marmot Creek were compared to gauged discharge over the sixseason period (Fig. 11). From May to July, the model predicted the spring increase in flow due to snowmelt with a peak in June and then a decline to much lower summer flows by July, with monthly MB ranging from -0.39 in June 2011 to 0.36 in May 2009. For August and September, the model tended to over-estimate discharge, with monthly MB ranging from 0.4 in September 2009 to 1.71 in September 2011. The overestimation of summer discharge was due to the model generating substantial runoff from rainstorms; rainfall-runoff is rarely observed to be large in Marmot Creek (Fig. 10). This may be associated with the model overestimating summer soil moisture storage and may reflect an underestimation of subsurface water storage capacity in some HRU. Nonetheless, the seasonal MB ranged from -0.08 to 0.12 , indicating that model was capable of predicting cumulative seasonal (i.e. May to September) discharge for Marmot Creek with only small biases. 
Table 6. Root mean square difference (RMSD, mm SWE), normalised RMSD (NRMSD), and model bias (MB) for the falsifying model simulations at Upper Forest/Clearing and Fisera Ridge sites, Marmot Creek Research Basin during seasons from 2007 to 2011.

\begin{tabular}{|c|c|c|c|c|c|c|c|}
\hline & \multicolumn{2}{|c|}{ Upper Forest/Clearing } & \multicolumn{5}{|c|}{ Fisera Ridge } \\
\hline & $\begin{array}{l}\text { Spruce } \\
\text { Forest }\end{array}$ & $\begin{array}{r}\text { Forest } \\
\text { Clearings }\end{array}$ & $\begin{array}{l}\text { North-facing } \\
\text { Slope }\end{array}$ & $\begin{array}{l}\text { Ridge } \\
\text { Top }\end{array}$ & $\begin{array}{l}\text { Top South- } \\
\text { facing Slope }\end{array}$ & $\begin{array}{l}\text { Bottom South- } \\
\text { facing Slope }\end{array}$ & $\begin{array}{l}\text { Larch } \\
\text { Forest }\end{array}$ \\
\hline RMSD & 54.6 & 39.8 & 235.7 & 176.6 & 106.9 & 259.5 & 240.0 \\
\hline NRMSD & 1.18 & 0.39 & 2.97 & 1.46 & 0.38 & 0.60 & 0.51 \\
\hline $\mathrm{MB}$ & 0.62 & -0.10 & 2.55 & 1.23 & -0.21 & -0.48 & -0.32 \\
\hline
\end{tabular}

\subsection{Model falsification}

Some aspects of the CRHM model created for Marmot Creek use algorithms that describe snow redistribution, sublimation and forest canopy effects on snowmelt, and evaporative processes that are rarely implemented in hydrological models. To investigate the contribution of these processes to model predictive capability, the model was "falsified" by deleting parameterisations for forest canopy snow mass and energy, blowing snow, intercepted rain evaporation, and sublimation from current model. The four-season (2007-2011) RMSD, NRMSD, and MB for the simulated snow accumulation at subalpine mature spruce forest and clearings sites (i.e. Upper Forest and Upper Clearing) and at alpine sites (i.e. Fisera Ridge) are shown in Table 6. Model falsification by ignoring forest canopy intercepted snow mass, energy, and sublimation contributed to a large increase in SWE errors for spruce forest HRUs. In the alpine tundra, removing blowing snow transport and sublimation processes resulted in snow no longer being redistributed from source HRUs (i.e. northfacing slope and ridge top) to sink HRUs (i.e. top and bottom south-facing slopes and larch forest) and an increase in model SWE error. For instance, the falsified simulations increased RMSD for SWE at spruce forest HRU to $54.6 \mathrm{~mm}$ from the original $19.4 \mathrm{~mm}$ listed in Table 3; a similarly large increase in RMSD for SWE was found for the north-facing slope, ridge top, and top and bottom south-facing slopes HRUs. In addition, the MB for the spruce HRU increased to 0.62 from the original value of 0.004 , and the MB rose to 2.55 and 1.23 for north-facing slope and ridge top HRUs from the original MB of 0.04 and -0.015 , respectively. The MB dropped to $-0.21,-0.48$ and -0.32 for top and bottom south-facing slopes and larch forest from original values of $-0.11,-0.006$ and 0.36 .

The consequences of these model falsifications for simulated daily streamflow are shown using NSE, RMSD, NRMSD, and MB in Table 7 over five seasons (2007-2011) for Cabin, Middle, and Twin creeks sub-basins as well as over six seasons (2006-2011) for Marmot Creek. Results show that the NSE dropped substantially, becoming small or negative for the sub-basins and only 0.22 for Marmot Creek itself; both RMSD and MB increased in the falsified simulations for all sub-basins as well as Marmot Creek basin
Table 7. Nash-Sutcliffe efficiency (NSE), root mean square difference (RMSD, $\mathrm{m}^{3} \mathrm{~s}^{-1}$ ), normalised RMSD (NRMSD), and model bias (MB) for the falsifying simulated daily mean streamflow discharge for Cabin Creek, Middle Creek, Twin Creek, and Marmot Creek.

\begin{tabular}{llrrl}
\hline & $\begin{array}{l}\text { Cabin } \\
\text { Creek }\end{array}$ & $\begin{array}{r}\text { Middle } \\
\text { Creek }\end{array}$ & $\begin{array}{r}\text { Twin } \\
\text { Creek }\end{array}$ & $\begin{array}{l}\text { Marmot } \\
\text { Creek }\end{array}$ \\
\hline NSE & 0.12 & -0.59 & 0.08 & 0.22 \\
RMSD & 0.040 & 0.124 & 0.105 & 0.200 \\
NRMSD & 0.84 & 1.01 & 0.81 & 0.82 \\
MB & 0.28 & -0.21 & -0.26 & 0.09 \\
\hline
\end{tabular}

discharge. This illustrates the importance and relevance of current model snow and forest parameterisations for Marmot Creek; without them, the model prediction of sub-basin and basin streamflow is substantially degraded.

\section{Discussion and conclusions}

A physically based hydrological model was set up in the CRHM platform for the Marmot Creek Research Basin, a headwater basin in the Canadian Rocky Mountains, based on the current understanding of the hydrological cycle in this basin. The good understanding of hydrology of the MCRB is due to the over $50 \mathrm{yr}$ of hydrological research in the basin. No calibration from streamflow was used in setting any parameters in the model, but the results of extensive scientific investigations of basin snow and hydrology were used where available and applicable. This is one of the first demonstrations of successful multivariate, multi-scale prediction of basin hydrology without any calibration from streamflow in a cold regions mountain environment and adds to the evidence provided by the approaches of Semenova et al. (2013) to parameterisation from basin understanding rather than calibration that are viable in these environments.

Various hydrological cycle components were simulated and evaluated against corresponding observations. Evaluations of snow accumulation and snowmelt revealed that the model performed well in the subalpine forest environments. This verifies that the major snow-related hydrological processes (e.g. snow interception, sublimation and unloading, 
shortwave extinction and longwave enhancement) were well represented in the recently added and modified modules of forest snow mass- and energy-balance (Ellis et al., 2010), longwave radiation (Sicart et al., 2006; Pomeroy et al., 2009), and energy-budget snowmelt (Marks et al., 1998). The predictions of snow accumulation and snowmelt also compared well with extensive snowpack observations on different aspects and landcovers (i.e. north-facing and southfacing slopes, ridge top, and forests) in the alpine and treeline environments, suggesting that the blowing snow redistribution and snowmelt calculations were accurate for most years. In the winter of 2009/2010, large model overestimations of SWE on the south-facing slope and larch forest sites suggest that the simplified blowing snow flow parameterisation might not be adequate in years with abnormal wind direction in the alpine environment. Varying wind flow directions during transport would have caused a deviation from the redistribution parameterisation in this PBSM implementation. Solutions to this will require explicit incorporation of wind direction measurements in modelling alpine snow redistribution and any improvement in model accuracy might then be offset by an increase in model complexity and parameter requirements.

Soil moisture evaluations showed the predicted seasonal pattern in soil moisture fluctuation matched observations quite well at the lodgepole pine site. This confirms that the model's snowmelt infiltration into frozen soils (Zhao and Gray, 1999), rainfall infiltration (Ayers, 1959), canopy interception (Ellis et al., 2010), and evaporation algorithms (Priestley and Taylor, 1972; Granger and Gray, 1989) were able to simulate the water dynamics and storage in the top soil layer for the lodgepole pine forest. Differences in mean values of soil moisture are most likely due to observation depths being shallower than modelling depths.

The results showed a weak positive correlation between the simulated groundwater storage and groundwater level fluctuation. Groundwater storage was predicted with the newly developed mountain hillslope module described in Sect. 3.2.6, in which storage capacity and drainage factor for lateral discharge in groundwater layer as well as the drainage factor for recharge (i.e. percolation) from the overlaid soil layer were simulated using a relatively simple conceptualisation of the groundwater system and groundwater-surfacewater interactions. This simple parameterisation might not be sufficiently detailed to simulate groundwater dynamics in a mountain basin. Successful groundwater simulations in mountain basins generally require finite difference subsurface flow models (e.g. Freeze and Harlan, 1969) and there was insufficient information to parameterise such a model in Marmot Creek at this time. Further research such as tracer experiment methods (Clow et al., 2003) or geophysical investigations such as that conducted by McClymont et al. (2010) and Langston et al. (2011) is warranted to improve the understanding of the groundwater system in Marmot Creek in support of improved modelling of surface water and groundwater interactions.

Simulations of streamflow discharge volumes were generally in close agreement with observed seasonal volumes at all scales, while the simulated hydrographs were well predicted at the basin scale and less well predicted at the subbasin scale. The improvement in hydrograph prediction with increasing scale is likely due to the following: (1) any modelling errors in single HRU becoming less important as scale increases, (2) better understanding of basin hydraulic characteristics at the low elevations that control streamflow near the main gauge, but not the sub-basin gauges, and (3) the emergence of streamflow routing over hillslope subsurface routing as the dominant process controlling hydrograph shape as scale increases. It should also be noted that the model spatial complexity was designed for basin-scale streamflow prediction, rather than sub-basin prediction. If the modelling objective had been prediction of a particular sub-basin, then a greater number of HRU and site specific selection of routing parameters would be expected to improve model performance. DeBeer (2012) demonstrated this in a series of highly successful snowmelt-driven streamflow simulations of Upper Middle Creek using CRHM with a more spatially complex model structure. It should be noted that no calibrations against streamflow were conducted for the parameters in the Muskingum routing, Clark's lag and route, and newly developed mountain hillslope modules. The parameters describing routing length, channel slope, Manning's roughness coefficient, hydraulic radius, soil saturated hydraulic conductivity, and pore size distribution index were determined based on GIS terrain analysis and lookup table values from surface and channel conditions and soil texture class. The less well simulated hydrographs for the sub-basins could likely be improved by introducing enhanced small-scale hillslope runoff routing parameterisations, but the scientific basis to set these is not sufficiently well understood at this time in Marmot Creek Research Basin.

This study has demonstrated an interesting and beneficial relationship between model development, field process studies, and a developing understanding of basin hydrology that can be a useful model for how to predict where streamflow measurements are not available. In this sense it has implications far beyond the Canadian Rockies and cold mountain basins. A hydrological model was constructed and applied based on improved basin hydrological understanding from several years of extensive site observations and process study. This improved understanding was used to develop and to parameterise the model, which was then tested against multiple types of observations that reflect differing hydrological cycle components of snow accumulation and melt, soil moisture, groundwater storage, and streamflow at various scales. Considering that the model is designed to predict the basin hydrological cycle rather than simply streamflow generation, it performed well in the multi-objective, multiscale evaluation. By selecting model parameters based on 
GIS terrain analysis, land cover, soil and geological surveys, field measurements, and lookup tables, the model required no calibration from streamflow. This has achieved one of the main objectives of the International Association of Hydrological Sciences Decade on Prediction in Ungauged Basins (PUB): that of prediction based on improved understanding rather than calibration (Sivapalan et al., 2003). This approach has worked well in Marmot Creek, which is one of the most well understood basins in the Canadian Rocky Mountains and where basin parameters have a relatively small uncertainty. However, this strategy can also contribute to guiding PUB approaches for modelling ungauged basins where basin information is less detailed. The model processes and physics appear to have simulated the hydrological cycle well and shown better prediction at the largest scale of evaluation. Using the approaches shown by Kuchment et al. (2000) and Semenova et al. (2013), parameters developed at Marmot Creek can be transferred to other basins for predictive purposes. Additional falsifying model simulations were instructive in demonstrating the importance and appropriateness of current model parameterisations for the Marmot Creek basin. Without these parameterisations of forest canopy snow mass and energy, sublimation, evapotranspiration, and alpine snow redistribution by wind, the model would have entirely misrepresented the snow mass balances and would have failed to predict streamflow accurately. This confirms the relevance of these parameterisations for other mountain basin with similar climate and vegetation. Given the global commonality of many cold regions hydrological processes (Gelfan et al., 2004) and the capability of transferring physically based parameters 1000s of $\mathrm{km}$ (Dornes et al., 2008b), the parameters determined from scientific investigations at Marmot Creek can likely be applied to ungauged basins at great distances, where there is little local information beyond meteorology, landcover and elevation. As atmospheric models, digital elevation models and satellite imagery provide improved and finer scale information every decade, there is little doubt that with the appropriate driving meteorology and physically realistic land surface parameters, that successful prediction of ungauged cold region mountain basins can be accomplished for the right scientific reasons and with adequate predictive ability. The inaccuracies of the model for groundwater regime, for streamflow at small sub-basin scales and for snow accumulation in certain treeline environments was also instructive and sets the agenda for the next phase of research, rather than the next phase of calibration.

Acknowledgements. The authors would like to gratefully acknowledge the funding assistance provided through the Alberta Department of Sustainable Resource Development, the IP3 Cold Regions Hydrology Network funded by the Canadian Foundation for Climate and Atmospheric Sciences, the Natural Sciences and Engineering Research Council of Canada through Discovery Grants, Research Tools and Instrument Grants and Alexander Graham Bell Scholarships, and the Canada Research Chairs programme. Logistical assistance was received from the Biogeoscience Institute, University of Calgary, and the Nakiska Ski Area and is greatly appreciated. Field work by many graduate students in and visitors to the Centre for Hydrology and research officers Michael Solohub and May Guan was essential in data collection. The authors also acknowledge Chris Hopkinson for his work on collecting and creating the lidar DEM for Marmot Creek. This paper is a contribution to the IAHS Decade for Prediction in Ungauged Basins (PUB).

Edited by: F. Fenicia

\section{References}

Alberta Forest Service.: Marmot Creek Watershed Research Basin: Forest Cover Type Map, Information and Technical Services Division, Graphics Section, Department of Forestry of Canada, Ottawa, Ontario, 1963.

Armstrong, R. N., Pomeroy, J. W., and Martz, L. W.: Estimating evaporation in a Prairie landscape under drought conditions, Can. Water Resour. J., 35, 173-186, 2010.

Aukema, B. H., Carroll, A. L., Zheng, Y., Zhu, J., Raffa, K. F., Moore, R. D., Stahl, K., and Taylor, S. W.: Movement of outbreak populations of mountain pine beetle: influence of spatiotemporal patterns and climate, Ecography, 31, 348-358, doi:10.1111/j.0906-7590.2007.05453.x, 2008.

Ayers, H. D.: Influence of soil profile and vegetation characteristics on net rainfall supply to runoff, in: Proceedings of Hydrology Symposium No. 1: Spillway Design Floods, National Research Council Canada, Ottawa, 198-205, 1959.

Beke, G. J.: Soils of three experimental watersheds in Alberta and their hydrological significance, Ph.D. thesis, Department of Soil Science, University of Alberta, Edmonton, Alberta, Canada, 456 pp., 1969.

Bernhardt, M., Zängl, G., Liston, G. E., Strasser, U., and Mauser, W.: Using wind fields from a high-resolution atmospheric model for simulating snow dynamics in mountainous terrain, Hydrol. Process., 23, 1064-1075, doi:10.1002/hyp.7208, 2009.

Beven, K. and Freer, J.: Equifinality, data assimilation, and uncertainty estimation in mechanistic modelling of complex environmental systems using the GLUE methodology, J. Hydrol., 249, 11-29, 2001.

Bewley, D., Alila, Y., and Varhola, A.: Variability of snow water equivalent and snow energetics across a large catchment subject to Mountain Pine Beetle infestation and rapid salvage logging, J. Hydrol., 388, 464-479, doi:10.1016/j.jhydrol.2010.05.031, 2010.

Boon, S.: Snow ablation energy balance in a dead forest stand, Hydrol. Process., 23, 2600-2610, doi:10.1002/hyp.7246, 2009.

Bowling, L. C., Pomeroy, J. W., and Lettenmaier, D. P.: Parameterisation of the sublimation of blowing snow in a macroscale hydrology model, J. Hydrometeorol., 5, 745-762, 2004.

Brooks, R. H. and Corey, A. T.: Hydraulic properties of porous media, Hydrology Paper 3, Colorado State University, Fort Collins, CO., 27 pp., 1964.

Brooks, R. H. and Corey, A. T.: Properties of porous media affecting fluid flow, J. Irrig. Drain. Div. Am. Soc. Civ. Eng., 92, 61-88, 1966. 
Brown, R. D. and Robinson, D. A.: Northern Hemisphere spring snow cover variability and change over 1922-2010 including an assessment of uncertainty, The Cryosphere, 5, 219-229, doi:10.5194/tc-5-219-2011, 2011.

Burles, K. and Boon, S.: Snowmelt energy balance in a burned forest plot, Crowsnest Pass, Alberta, Canada, Hydrol. Process., 25, 3012-3029, doi:10.1002/hyp.8067, 2011.

Chow, V. T.: Open Channel Hydraulics, McGraw-Hill, Inc., New York, 1959.

Chow, V. T.: Handbook of Applied Hydrology, McGraw-Hill, Inc., New York, 1964.

Clapp, R. B. and Hornberger, G. M.: Empirical equations for some soil hydraulic properties, Water Resour. Res., 14, 601-604, 1978.

Clark, C. O.: Storage and the unit hydrograph, Proc. Am. Soc. Civil Eng., 69, 1419-1447, 1945.

Clow, D. W., Schrott, L., Webb, R., Campbell, D. H., Torizzo, A., and Dorblaser, M.: Ground water occurrence and contributions to streamflow in an alpine catchment, Colorado Front range, Ground Water, 41, 937-950, 2003.

DeBeer, C. M.: Simulating areal snowcover depletion and snowmelt runoff in alpine terrain, $\mathrm{PhD}$ thesis, Department of Geography and Planning, University of Saskatchewan, Saskatoon, Saskatchewan, Canada, 251 pp., 2012.

DeBeer, C. M. and Pomeroy, J. W.: Modelling snow melt and snowcover depletion in a small alpine cirque, Canadian Rocky Mountains, Hydrol. Process., 23, 2584-2599, doi:10.1002/hyp.7346, 2009.

DeBeer, C. M. and Pomeroy, J. W.: Simulation of the snowmelt runoff contributing area in a small alpine basin, Hydrol. Earth Syst. Sci., 14, 1205-1219, doi:10.5194/hess-14-12052010, 2010.

Doorschot, J., Raderschall, N., and Lehning, M.: Measurements and one-dimensional model calculations of snow transport over a mountain ridge, Ann. Glaciol., 32, 153-158, 2001.

Dornes, P. F., Pomeroy, J. W., Pietroniro, A., Carey, S. K., and Quinton, W. L.: Influence of landscape aggregation in modelling snow-cover ablation and snowmelt runoff in a sub-arctic mountainous environment, Hydrolog. Sci. J., 53, 725-740, 2008a.

Dornes, P. F., Tolson, B. A., Davison, B., Pietroniro, A., Pomeroy, J. W., and Marsh, P.: Regionalisation of land surface hydrological model parameters in subarctic and arctic environments, Phys. Chem. Earth, 33, 1081-1089, doi:10.1016/j.pce.2008.07.007, 2008b.

Ellis, C. R. and Pomeroy, J. W.: Estimating sub-canopy shortwave irradiance to melting snow on forested slopes, Hydrol. Process., 21, 2581-2593, doi:10.1002/hyp.6794, 2007.

Ellis, C. R., Pomeroy, J. W., Brown, T., and MacDonald, J.: Simulation of snow accumulation and melt in needleleaf forest environments, Hydrol. Earth Syst. Sci., 14, 925-940, doi:10.5194/hess14-925-2010, 2010.

Ellis, C. R., Pomeroy, J. W., Essery, R. L. H., and Link, T. E.: Effects of needleleaf forest cover on radiation and snowmelt dynamics in the Canadian Rocky Mountains, Can. J. Forest Res., 41, 608620, doi:10.1139/X10-227, 2011.

Ellis, C. R., Pomeroy, J. W., and Link, T. E.: Modeling increases in snowmelt yield and desynchronization resulting from forest gap thining treatments in a northern mountain catchment, Water Resour. Res., 49, 936-949, doi:10.1002/wrcr.20089, 2013.
Essery, R., Pomeroy, J., Ellis, C., and Link, T.: Modelling longwave radiation to snow beneath forest canopies using hemispherical photography or linear regression, Hydrol. Process., 22, 27882800, doi:10.1002/hyp.6930, 2008.

Fang, X., Pomeroy, J. W., Westbrook, C. J., Guo, X., Minke, A. G., and Brown, T.: Prediction of snowmelt derived streamflow in a wetland dominated prairie basin, Hydrol. Earth Syst. Sci., 14, 991-1006, doi:10.5194/hess-14-991-2010, 2010.

Fauria, M. M. and Johnson, E. A.: Large-scale climatic patterns control large lightning fire occurrence in Canada and Alaska forest regions, J. Geophys. Res., 111, G04008, doi:10.1029/2006JG000181, 2006.

Föhn, P. M. B. and Meister, R.: Distribution of snow drifts on ridge slopes, Ann. Glaciol., 4, 52-57, 1983.

Freeze, R. A. and Harlan, R. L.: Blueprint for a physically-based, digitally-simulated hydrologic response model, J. Hydrol., 9, 237-258, 1969.

Garnier, B. J. and Ohmura, A.: The evaluation of surface variations in solar radiation income, Sol. Energy, 13, 21-34, 1970.

Gelfan, A., Pomeroy, J. W., and Kuchment, L.: Modelling forestcover influences on snow accumulation, sublimation and melt, J. Hydrometeorol., 5, 785-803, 2004.

Golding, D. L. and Swanson, R. H.: Snow distribution patterns in clearings and adjacent forest, Water Resour. Res., 22, 19311940, 1986.

Granger, R. J. and Gray, D. M.: Evaporation from natural nonsaturated surfaces, J. Hydrol., 111, 21-29, 1989.

Granger, R. J. and Gray, D. M.: A new radiation model for calculating daily snowmelt in open environments, Nord. Hydrol., 21, 217-234, 1990.

Granger, R. J. and Pomeroy, J. W.: Sustainability of the western Canadian boreal forest under changing hydrological conditions $-2-$ summer energy and water use, in: Sustainability of Water Resources under Increasing Uncertainty, edited by: Rosjberg, D., Boutayeb, N., Gustard, A., Kundzewicz, Z., and Rasmussen, P., IAHS Publication No. 240, IAHS Press, Wallingford, UK, 243250, 1997.

Gray, D. M. and Male, D. H. (Eds.): Handbook of Snow: Principles, Processes, Management and Use, Pergamon Press, Toronto, Canada, 776 pp., 1981.

Harding, R. J. and Pomeroy, J. W.: The energy balance of the winter boreal landscape, J. Climate, 9, 2778-2787, 1996.

Hedstrom, N. R. and Pomeroy, J. W.: Measurements and modelling of snow interception in the boreal forest, Hydrol. Process., 12, 1611-1625, 1998.

Henderson, F. M. and Wooding, R. A.: Overland flow and groundwater flow from a steady rainfall of finite duration, J. Geophys. Res., 69, 1531-1540, 1964.

Hendry, M. J.: Hydraulic conductivity of a glacial till in Alberta, Ground Water, 20, 162-169, 1982.

Hopkinson, C., Pomeroy, J. W., DeBeer, C., Ellis, C., and Anderson, A.: Relationships between snowpack depth and primary LiDAR point cloud derivatives in a mountainous environment, Remote Sensing and Hydrology 2010, IAHS Publ. 352, IAHS Press, Jackson Hole, Wyoming, 2012.

Jeffrey, W. W.: Experimental watersheds in the Rocky Mountains, Alberta, Canada, in: Symposium of Budapest, Proceedings of the Symposium on Representative and Experimental Areas, 28 September-5 October 1965, Budapest, Hungary, 502-521, 
1965.

Kirby, C. L. and Ogilvy, R. T.: The forest of Marmot Creek watershed research basin, Canadian Forestry Service Publication No. 1259, Canadian Department of Fisheries and Forestry, Ottawa, Ontario, 37 pp., 1969.

Kshirsagar, M. M., Rajagopalan, B., and Lall, U.: Optimal parameter estimation for Muskingum routing with ungauged lateral inflow, J. Hydrol., 169, 25-35, 1995.

Kuchment, L. S., Gelfan, A. N., and Demidov, V. N.: A distributed model of runoff generation in the permafrost regions, J. Hydrol., 240, 1-22, 2000.

Langston, G., Bentley, L. R., Hayashi, M., McClymont, A., and Pidlisecky, A.: Internal structure and hydrological functions of an alpine proglacial moraine, Hydrol. Process., 25, 2967-2982, doi:10.1002/hyp.8144, 2011.

Lapp, S., Byrne, J., Townshend, I., and Kienzle, S.: Climate warming impacts on snowpack accumulation in an alpine watershed, Int. J. Climatol., 25, 521-536, 2005.

Leavesley, G. H., Lichty, R. W., Troutman, B. M., and Saindon, L. G.: Precipitation-runoff modelling system: user's manual, WaterResources Investigations Report 83-4238, US Geological Survey, Reston, Virginia, 1983.

Link, T. E., Marks, D., and Hardy, J. P.: A deterministic method to characterize canopy radiative transfer properties, Hydrol. Process., 18, 3583-3594, doi:10.1002/hyp.5793, 2004.

Lundberg, A. and Halldin, S.: Evaporation of intercepted snow, analysis of governing factors, Water Resour. Res., 30, 25872598, 1994.

MacDonald, J.: Unloading of intercepted snow in conifer forests, M.Sc. thesis, Department of Geography and Planning, University of Saskatchewan, Saskatoon, Saskatchewan, Canada, 93 pp., 2010.

MacDonald, J. and Pomeroy, J. W.: Gauge undercatch of two common snowfall gauges in a prairie environment, in: Proceedings of the 64th Eastern Snow Conference, 29 May-1 June 2007, St. John's, Newfoundland, Canada, 119-126, 2007.

MacDonald, M. K., Pomeroy, J. W., and Pietroniro, A.: On the importance of sublimation to an alpine snow mass balance in the Canadian Rocky Mountains, Hydrol. Earth Syst. Sci., 14, 14011415, doi:10.5194/hess-14-1401-2010, 2010.

MacDonald, R. J., Byrne, J. M., Kienzle, S. W., and Larson, R. P.: Assessing the potential impacts of climate change on mountain snowpacks in the St. Mary River watershed, Montana, J. Hydrometeorol., 12, 262-273, doi:10.1175/2010JHM1294.1, 2011.

Mannix, A. E., Dridi, C., and Adamowicz, W. L.: Water availability in the oil sands under projections of increasing demands and a changing climate: an assessment of Lower Athabasca water management framework (phase 1), Can. Water Resour. J., 35, 29-52, 2010.

Marks, D., Kimball, J., Tingey, D., and Link, T.: The sensitivity of snowmelt processes to climate conditions and forest cover during rain-on-snow: a case study of the 1996 Pacific Northwest flood, Hydrol. Process., 12, 1569-1587, 1998.

Marks, D., Winstral, A., Reba, M., Pomeroy, J., and Kumar, M.: An evaluation of methods for determining during-storm precipitation phase and the rain/snow transition elevation at the surface in a mountain basin, Adv. Water Resour., online first, doi:10.1016/j.advwatres.2012.11.012, 2013.
Marsh, C. B., Pomeroy, J. W., and Spiteri, R. J.: Implications of mountain shading on calculating energy for snowmelt using unstructured triangular meshes, Hydrol. Process., 26, 1767-1778, doi:10.1002/hyp.9329, 2012.

Marsh, P. and Pomeroy, J. W.: Meltwater fluxes at an arctic foresttundra site, Hydrol. Process., 10, 1383-1400, 1996.

Mays, L. W.: Water Resources Engineering, John Wiley \& Sons, Inc., New York, 2001.

McClymont, A. F., Hayashi, M., Bentley, L. R., Muir, D., and Ernst, E.: Groundwater flow and storage within an alpine meadow-talus complex, Hydrol. Earth Syst. Sci., 14, 859-872, doi:10.5194/hess-14-859-2010, 2010.

Nash, J. E. and Sutcliffe, J. V.: River flow forecasting through conceptual models, Part I - A discussion of principles, J. Hydrol., 10, 282-290, 1970.

Pietroniro, A., Fortin, V., Kouwen, N., Neal, C., Turcotte, R., Davison, B., Verseghy, D., Soulis, E. D., Caldwell, R., Evora, N., and Pellerin, P.: Development of the MESH modelling system for hydrological ensemble forecasting of the Laurentian Great Lakes at the regional scale, Hydrol. Earth Syst. Sci., 11, 1279-1294, doi:10.5194/hess-11-1279-2007, 2007.

Pomeroy, J. W. and Gray, D. M.: Snowcover Accumulation, Relocation and Management, NHRI Science Report No. 7, Environment Canada, Saskatoon, Canada, 144 pp., 1995.

Pomeroy, J. W. and Li, L.: Prairie and arctic areal snow cover mass balance using a blowing snow model, J. Geophys. Res., 105, 26619-26634, 2000.

Pomeroy, J. W., Parviainen, J., Hedstrom, N., and Gray, D. M.: Coupled modelling of forest snow interception and sublimation, Hydrol. Process., 12, 2317-2337, 1998.

Pomeroy, J. W., Gray, D. M., Hedstrom, N. R., and Janowicz, J. R.: Prediction of seasonal snow accumulation in cold climate forests, Hydrol. Process., 16, 3543-3558, doi:10.1002/hyp.1228, 2002.

Pomeroy, J. W., Toth, B., Granger, R. J., Hedstrom, N. R., and Essery, R. L. H.: Variation in surface energetics during snowmelt in a subarctic mountain catchment, J. Hydrometeorol., 4, 702-719, 2003.

Pomeroy, J. W., Gray, D. M., Brown, T., Hedstrom, N. R., Quinton, W., Granger, R. J., and Carey, S.: The Cold Regions Hydrological Model, a platform for basing process representation and model structure on physical evidence, Hydrol. Process., 21, 2650-2667, doi:10.1002/hyp.6787, 2007.

Pomeroy, J. W., Marks, D., Link, T., Ellis, C., Hardy, J., Rowlands, A., and Granger, R.: The impact of coniferous forest temperature on incoming longwave radiation to melting snow, Hydrol. Process., 23, 2513-2525, doi:10.1002/hyp.7325, 2009.

Pomeroy, J. W., Fang, X., and Ellis, C.: Sensitivity of snowmelt hydrology in Marmot Creek, Alberta, to forest cover disturbance, Hydrol. Process., 26, 1892-1905, doi:10.1002/hyp.9248, 2012.

Priestley, C. H. B. and Taylor, R. J.: On the assessment of surface heat flux and evaporation using large-scale parameters, Mon. Weather Rev., 100, 81-92, 1972.

Reba, M. L., Pomeroy, J., Marks, D., and Link, T. E.: Estimating surface sublimation losses from snowpacks in a mountain catchment using eddy covariance and turbulent transfer calculations, Hydrol. Process., 26, 3699-3711, doi:10.1002/hyp.8372, 2012.

Rex, J. and Dubé, S.: Predicting the risk of wet ground areas in the Vanderhoof Forest District: Project description and progress report, BC J. Ecosyst. Manage., 7, 57-71, 2006. 
Rutter, N., Essery, R., Pomeroy, J., Altimir, N., Andreadis, K., Baker, I., Barr, A., Bartlett, P., Boone, A., Deng, H., Douville, H., Dutra, E., Elder, K., Ellis, C., Feng, X., Gelfan, A., Goodbody, A., Gusev, Y., Gustafsson, D., Hellström, R., Hirabayashi, Y., Hirota, T., Jonas, T., Koren, V., Kuragina, A., Lettenmaier, D., Li, W.-P., Martin, E., Nasanova, O., Pumpanen, J., Pyles, R., Samuelsson, P., Sandells, M., Schadler, G., Shmakin, A., Smirnova, T., Stahli, M., Stockli, R., Strasser, U., Su, H., Suzuki, K., Takata, K., Tanaka, K., Thompson, E., Vesala, T., Viterbo, P., Wiltshire, A., Xia, K., Xue, Y., and Yamazaki, T.: Evaluation of forest snow process models (SnowMip2), J. Geophys. Res., 114, D06111, doi:10.1029/2008JD011063, 2009.

Sabzevari, T., Talebi, A., Ardakanian, R., and Shamsai, A.: A steady-state saturation model to determine the subsurface travel time (STT) in complex hillslopes, Hydrol. Earth Syst. Sci., 14, 891-900, doi:10.5194/hess-14-891-2010, 2010.

Schmidt, R. A. and Gluns, D. R.: Snowfall interception on branches of three conifer species, Can. J. Forest Res., 21, 1262-1269, 1991.

Semenova, O., Lebedeva, L., and Vinogradov, Y.: Simulation of subsurface heat and water dynamics, and runoff generation in mountainous permafrost conditions, in the Upper Kolyma River basin, Russia, Hydrogeol. J., 21, 107-119, 2013.

Sicart, J. E., Pomeroy, J. W., Essery, R. L. H., Hardy, J., Link, T., and Marks, D.: A sensitivity study of daytime net radiation during snowmelt to forest canopy and atmospheric conditions, J. Hydrometeorol., 5, 774-784, 2004.

Sicart, J. E., Pomeroy, J. W., Essery, R. L. H., and Bewley, D.: Incoming longwave radiation to melting snow: observations, sensitivity and estimation in northern environments, Hydrol. Process., 20, 3697-3708, doi:10.1002/hyp.6383, 2006.

Sivapalan, M., Takeuchi, K., Franks, S. W., Gupta, V. K., Karambiri, H., Lakshmi, V., Liang, X., McDonnell, J. J., Mendiondo, E. M., O'Connell, P. E., Oki, T., Pomeroy, J. W., Schertzer, D., Uhlenbrook, S., and Zehe, E.: IAHS Decade on Predictions in Ungauged Basins (PUB), 2003-2012: Shaping an exciting future for the hydrological sciences, Hydrolog. Sci. J., 48, 857-880, 2003.

Stankovich, J. M. and Lockington, D. A.: Brooks-Corey and van Genuchten soil-water-retention models, J. Irrig. Drain. Eng., 121, $1-7,1995$.

Stevenson, D. R.: Geological and groundwater investigations in the Marmot Creek experimental basin of southwestern Alberta, Canada, M.Sc. Thesis, Department of Geology, University of Alberta, Edmonton, Alberta, 106 pp., 1967.

Stewart, I. T., Cayan, D. R., and Dettinger, M. D.: Changes in snowmelt runoff timing in western North America under a "business as usual" climate change scenario, Climatic Change, 62, 217-232, 2004.
St. Jacques, J.-M., Sauchyn, D. J., and Zhao, Y.: Northern Rocky Mountain streamflow records: Global warming treands, human impacts or natural variability?, Geophys. Res. Lett., 37, L06407, doi:10.1029/2009GL042045, 2010.

Storr, D.: Precipitation variations in a small forested watershed, in: Proceedings of the 35th Western Snow Conference, 1820 April 1967, Boise, Idaho, USA, 11-17, 1967.

Swanson, R. H.: Forest hydrology issues for the $21^{\text {st }}$ century: A consultant's viewpoint, J. Am. Water Resour. Assoc., 34, 755763, 1998.

Varhola, A., Coops, N. C., Weiler, M., and Moore, R. D.: Forest canopy effects on snow accumulation and ablation: An integrative review of empirical results, J. Hydrol., 392, 219-233, doi:10/1016/j.hydrol.2010.08.009, 2010.

Verseghy, D. L.: CLASS-A Canadian land surface scheme for GCMs, I. soil model, Int. J. Climatol., 11, 111-133, 1991.

Wallis, P. M., Hynes, H. B. N., and Talang, S. A.: The importance of groundwater in the transportation of allochthonous dissolved organic matter to the streams draining a small mountain basin, Hydrobiologia, 79, 77-90, 1981.

Whitaker, A., Alila, Y., Beckers, J., and Toews, D.: Evaluating peak flow sensitivity to clear-cutting in different elevation bands of a snowmelt-dominated mountainous catchment, Water Resour. Res., 38, 1172, doi:10.1029/2001WR000514, 2002.

Woods, A., Coates, K. D., and Hamann, A.: Is an unprecedented dothistroma needle blight epidemic related to climate change?, BioScience, 55, 761-769, 2005.

Wu, J. S., King, E. L., and Wang, M.: Optimal identification of Muskingum routing coefficients, Water Resour. Bull., 21, 417421, 1985.

Zhang, Y., Carey, S. K., Quinton, W. L., Janowicz, J. R., Pomeroy, J. W., and Flerchinger, G. N.: Comparison of algorithms and parameterisations for infiltration into organic-covered permafrost soils, Hydrol. Earth Syst. Sci., 14, 729-750, doi:10.5194/hess14-729-2010, 2010.

Zhang, Z., Kane, D. L., and Hinzman, L. D.: Development and application of a spatially-distributed Arctic hydrological and thermal process model (ARHYTHM), Hydrol. Process., 14, 10171044, 2000.

Zhao, L. and Gray, D. M.: Estimating snowmelt infiltration into frozen soils, Hydrol. Process., 13, 1827-1842, 1999. 